\title{
Bpotós. A favourite word of Homer in the Septuagint version of Job
}

\author{
Evangelia G Dafni ${ }^{1}$ \\ (University of Essen - Duisburg and Pretoria)
}

\begin{abstract}
Bpotós. A favourite word of Homer in the Septuagint version of Job
\end{abstract}

Bpotós, a favourite word used by Homer, appears exclusively in the Septuagint version of Job to express the beauty of the whole man, as an excellent creature of God, who is transient but strives to achieve eternity. He is vulnerable but wants to reach perfection, is mortal and longs for immortality. This equivalent enables us to decode translation processes in the $L X X$-Job and to uncover hermeneutical principles and characteristics of its theological and anthropological language and thought.

\section{INTRODUCTION}

One of the most admirable ways in which the Septuagint translators rendered the meaning of the original into Greek, is found especially in their efforts to transfer poetry from Hebrew into Greek by using epical-poetical language. From the vocabulary they employed, we can conclude that the translators of the poetical books of the Hebrew Old Testament preferred the way of formal transformation and new

\footnotetext{
* Supported by the Alexander von Humboldt Foundation. First presented by the SBL-International Meeting at the Pontificia Università Gregoriana, Pontificio Instituto Biblico, on the 11th July 2001 in Rome (Dafni 2001a), and also at both the Universities of Pretoria and Stellenbosch in October and November 2006 respectively. Some aspects were discussed extensively in my seminars at the Faculty of Humanities, Duisburg-Essen University (http://www.uniessen.de/Ev-Theologie/courses/dafni-homer2003.htm). The additional remarks on the topics “Old Greek version”, "meanings and intentions of a translated text”, “poetic and divine inspiration”, “Theology of the LXX”, “Theology of the LXX-Language" in excurses and footnotes are a response to Horacio Simian-Yofre's comments on the present contribution. The additions do not change the original concept at all, but they indicate the manner of coming to grips with our question of Theology of the Septuagint language in the horizon of the Ancient Greek literature and thought.

1 Dr Dafni is a research fellow of the Department of Old Testament Studies, Faculty of Theology, University of Pretoria.
} 
creation of free poetical styles, rather than the way of a reconstruction or exact imitation of given Hebrew poetical forms and structures. These efforts are reflected especially in the Septuagint of the book of Job. The Septuagint-Job, which is about $1 / 6^{\text {th }}$ shorter than the Masoretic text, avoids the strict exactness of words in the translation and rather tries to understand the deeper meaning and intention of the Hebrew source text ${ }^{2}$ and to reproduce its spirit by applying hermeneutical principles and rules which follow Ancient Greek lines of poetical thought. According to Henry St J Thackeray, the translator of the book of Job "was a student of the Greek poets; his version was probably produced for the general reader, not for the synagogues”3. Subsequently, Thackeray ascribes the LXX-Job to a sole translator and gives answer to the key-question of its life-

2 The conviction, that, "in order to make a comparison between the Hebrew and the Greek text is absolutely necessary to establish the Old Greek version as a base", has more than one logical and methodological weakness due to the fact that we today only have eclectic or diplomatic Hebrew and Greek text editions, namely reconstructed texts and texts which are based on the oldest complete preserved codex. Since the discovery of the Qumran texts we know that neither the MT nor the LXX is identical with the so-called Original text. They are only representative text-forms or text-types. Therefore, both of them should first and foremost be seen as texts in their own rights. The LXX represents a complete translation corpus of Hebrew originals from the 3rd to the 1st century BC, which are lost and can only be reconstructed on the basis of comparisons with the MT. The oldest complete manuscript of the LXX, Codex Vaticanus, goes back to the 4th century AD. The MT represents the only reliable, complete text of the Hebrew Bible. Its oldest complete manuscript is the Codex Petropolitanus / Leningradensis from the 10th century AD. Critical editions offer eclectic texts and are definitely not identical with the Original text. That means they are rather representative of text- and theologically motivated decisions of modern editors, as opposed to the so-called UrSeptuaginta, the translation done by the original Jewish translators. They are interesting because they offer several other readings so that the reader becomes aware of the fact that not only one single version but more versions were circulating in Antiquity. Eclectic texts have never really existed in this form. The old codices are real texts and therefore we should rather trust what is nearer to the LXX-origins, than the decision of an editor who definitely does not have the natural language feeling of Greek and Hebrew, and is determined to have different ideological and theological presuppositions than the original translators.

3 Thackeray (1915, http://www.bible.researcher.com/isbelxx). 
setting. If correct, Thackeray identifies a crucial factor when trying to understand its high-reflected poetical language.

It is noteworthy that Homeric vocabulary was quite often consulted by the LXX-Job ${ }^{4}$. A characteristic example is the word

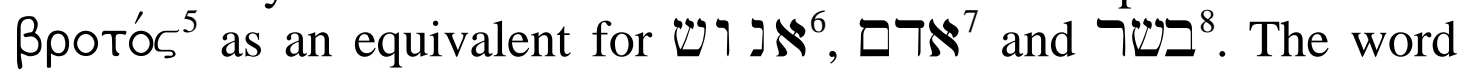
שS is a collective term, widely attested in the Ancient Semitic Languages. It occurs relatively rare within the Hebrew Scriptures, most frequently in the book of Job and its precise meaning is controversial ${ }^{9}$. $\boldsymbol{\Sigma}^{10}$ and ${ }^{11}$, however, are employed by the Hebrew Old Testament authors as collective terms a) to describe mankind as God's creation, and b) to reflect in its historic frailty. In this sense, the equivalent ßpotós enables us not only to decode translation processes in the book of Job, but also to uncover hermeneutical principles and characteristics of its theological and anthropological language.

Bpotós, Homer's favourite word, appears as translation equivalent exclusively in the LXX-Job. It recurs more regularly as

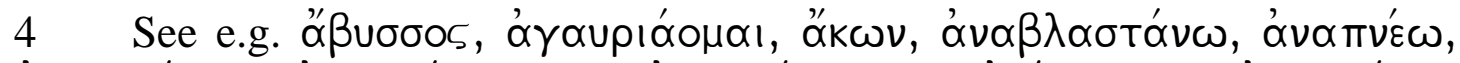

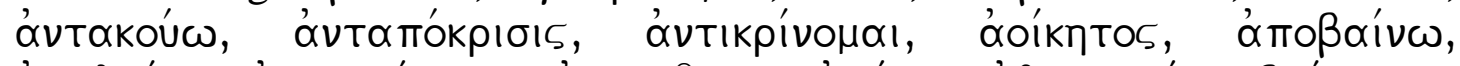

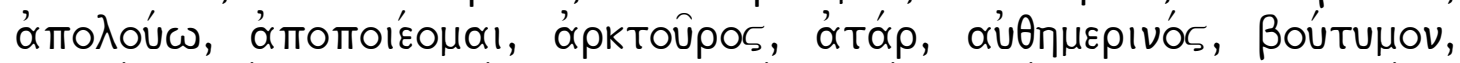

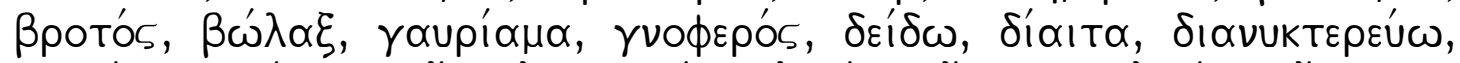

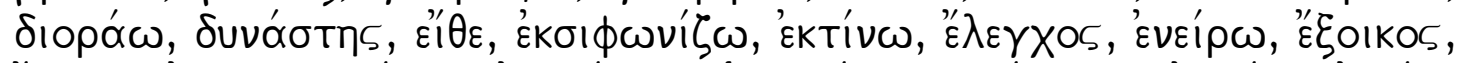

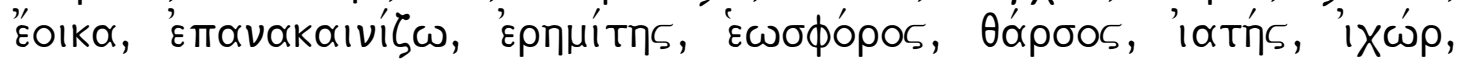

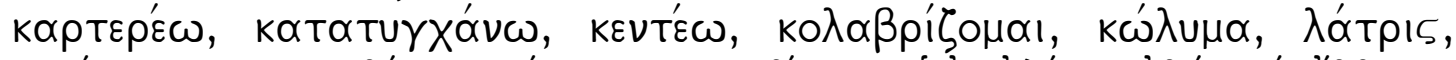

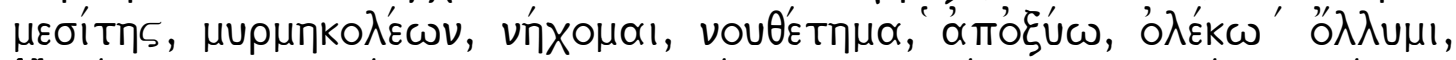

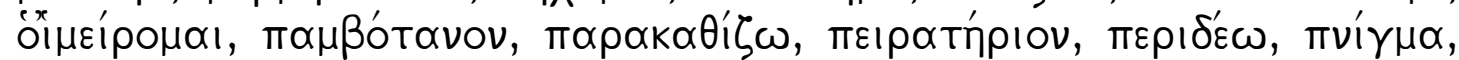

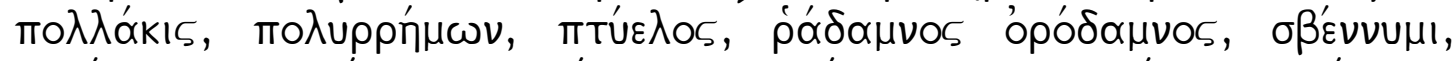

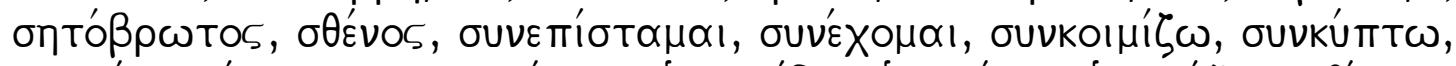

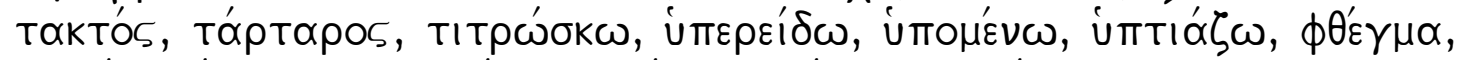

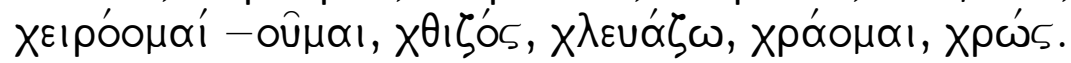

$5 \quad$ Job 4:17; 9:2; 10:4.22; 11:12; 14:1.10; 15:14; 25:4; 28:4.13; 32:8.21; 33:12; 34:15; 36:25.28.

$6 \quad$ Job 4:17; 9:2; 15:14; 25:4; 28,4.13; 32:8; 33:12(?); 36:25(?).

7 Job 11:12(?); 14:1.10; 32:21; 34:15.

8 Only Job 10:4a.

$9 \quad$ See Maass (1973:373-375). Cf. Westermann (1971: 43-44).

10 Westermann (1971: 41-57). Maass (1973:81-94).

11 Bratsiotis (1973:850-867). Cf. Gerleman (1971:376-379). 
embossed term in the Intertestamental writings ${ }^{12}$. It is, however, not found in the New Testament, though in the Hymnography of the Ancient Church ${ }^{13}$.

An approximate English translation of ßpotós is "mortal man" (LSJ 331). A similar semantic equation is also found in German lexica: "sterblich”, “der Sterbliche”. These semantic choices seem to provide the necessary pragmatic horizon for a certain understanding with regard to the nature and the value of this translation equivalent. The Greek word in question, however, can be understood and explained in more than one way. The decision about its meaning and significance depends on a) the theological and anthropological relevance of the word Bpotós up till now, and b) the inner structure of its Greek meanings and intentions in the Septuagint $^{14}$.

When analysing the historic-semantic background of ßpotós as a translation equivalent, its Homeric heritage should be taken into account as well. Of course, the Homeric language can be described in various ways. But from my perspective it is crucial to analyse the following issues: Did the meaning of Bpotós remain static or diverge progressively, and how could the semantic wingspan from Homer to LXX-Job be reconstructed? Did the Job-translator correctly understand his original source text and really made lexical, as well as mental adoptions from the Homeric Epics? Or did he rather slavishly imitate Homeric style and blindly promulgate specific Homeric forms in his own translation in order to reflect the nature of Homeric ways of thinking? How are his translation procedures to be legitimatised?

12 See e.g. Philo, De aeternitate mundi 121.7.

13 See e.g. Romanus Melodus, Cantica 2.7.6, comment to Gen 6f.: Tò

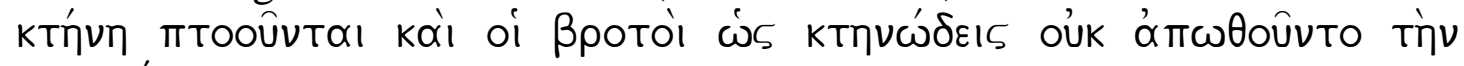
поипрíav.

14 It must be paid attention to the fact that an approach to the "meanings and intensions" of a translated text can definitely not only be deducted from the context and the network of relations that words have in the Greek linguistic system. The LXX-language should be understood as a balance of the translators' Greek education and their Jewish identity based on their belief in Yahweh, the revealed God of Israel. 
The present study aims to rediscover the inner unity of the abovementioned questions especially in view of a reconstruction of the Theology of the language of the Septuagint-Job ${ }^{15}$.

The Theology of the Septuagint should be seen as the crown of every philological and theological activity in the field of the LXX-studies, because it deals with central theological issues regarding the Greek Old Testament's belief in one single God (Dafni 2003). Since the Old Testament is not simply a book, but a library which consists of several books, written by different individuals during the course of thousand years, which reflects very old oral traditions differing in form and content, the question of the modifiability of perceptions and depictions of God in Ancient Israel arises. Regarding the LXX, this question must be put on the table as follows: If the LXX has really been translated in the course of two and a half centuries by different individuals, then how did they understand, explain and translate potential changes of perception of God and modifications of expressions referring to God? And how could we today explain the processes described there?

15 In the last three decades, LXX-scholars raise the following questions: a) How should the LXX be understood? Is it just a translation, or rather a theological document of the early Jewish tradition? Is it a valid part of this tradition, or is it only a reflection of it? Can we assume that the translators of the Greek Bible are inspired by Ancient Greek authors or did they follow closely the wording of Ancient Greek texts as well? When scholars raise especially the latter question, then it is obvious that they consciously or unconsciously link and sometimes mix poetic inspiration, which refers only to the formal aspect of the scriptural texts, and divine inspiration of the Holy Scriptures as the encounter of divine revelation and mental and psychical capacity of the scriptural authors. For other scholars, however, it is clear enough that investigations of biblical vocabulary and the attempt to give an explanation of how the text-semantics and the theology of a text are joined together, refer to theological ideas which we can always reconstruct on the basis of a given text form, but we definitely do not investigate the nature of the divine revelation. This attempt certainly does not deny the divine factor, but acknowledges the limitations of human ratio, as well as the limitations of human language to express "more precisely", "thoroughly" and "accurately" experiences of divine revelation. 
The term Theology of the Septuagint can mean both a) the theology that is really contained and detected in the Corpus of the Greek Old Testament, as well as b) the theology developed from the LXX by Christian theologians (cf Dafni 1999, 2001a, 2001b, 2002, 2003, 2006a.b). This last attempt presupposes certain value judgments as well as certain attitudes of the LXX-scholar as a theologian with regard to the subject of his research. For this reason, scholars should feel obliged to their readers to clarify how they define the term Theology of the Septuagint and with which definition they are dealing.

In my opening lecture at the IOSCS-Congress in Basel in 2001 (Dafni 2002), I introduced the term "Theology of the Septuagint Language" in order to contribute to the possibility of writing a Theology of the Septuagint in its own right ${ }^{16}$. Of course, I used the word "theology" as a collective term, which includes "theologies" as sub-areas of the historical-critical analysis. In my view, Theology of the Septuagint in its own right can only be the Theology which is based on quantitative or qualitative, intended or unintended differences among Hebrew text forms and the LXX-versions. For what is common between Hebrew and Old Greek versions can only be understood as theological inheritance of the whole Old Testament. The points

16 Modern LXX-scholars often make the unfounded assertion that "the translators of the Septuagint were mainly translators and not theologians", so that if one asks about the theology on the basis of the language used in the LXX, "it gives the impression of an eisegesis that supplants exegesis". The question we have to ask is, whether it is possible for anybody working with or on the Bible, a theological book katexochen, without giving theological thoughts about theological contents at all? And how is one to explain that the Septuaginta were only translators and not theologians in spite of fact that the written and the oral Torah as well as the Prophets and the other holy writings had been given as an inheritance to the Jewish people whose task was to understand, explain and transmit it to the present and the future generations? Had the LXX-translators not been working in this sense, then we have to assume that they were no Jewish people, but West European enlightened linguists. These assertions devaluate the translators as teachers of their theological inheritance, and aim at eliminating the LXX as a theological work. 
where both the Hebrew and the Greek text versions differ quantitatively or qualitatively, could be characteristic of another or even a new understanding. Theologically speaking, this could be either a hint of developmental phases of the divine revelation or a sign of the degree and extent to which the human capacity can record the divine truth in written texts.

When dealing with such a question, we then have to be conscious of the fact that we are no longer on the area of text-linguistics, but on the area of metaphysics. The arguments do not have the same value anymore. Therefore, we have to be aware of the danger of mixing arguments and results of our investigation. It is not allowed to use linguistic arguments to ground metaphysical judgments or to abuse metaphysical prejudgments in order to criticize pure linguistic analysis. That is why we definitely need methodological criticism. Correctly understood, Theology of the Septuagint Language embraces methodological and philological criticism as well, but methodological or philological criticism without reflection on the Theology of the Language of the Septuagint remains unsubstantial and directionless.

\section{SOME LEXICOGRAPHICAL REMARKS}

The focus of the following remarks is indeed not on how to justify models of modern theoretical semantics which could only hardly contribute to a deeper understanding of the Greek language and thought $^{17}$ in comparison to the Hebrew. My aim is to chose and

17 Modern LXX-studies are deeply affected by the limited knowledge of Greek language and thought in its development and diachronic unity from the Mycenean era up till to now, as well as the enforcement of humanistic prejudices against the language and its native speakers. Cf. Caragounis (2004). The Theologisches Wörterbuch zum Neuen Testament tried to bridge the gap between Greek meanings and intentions, from Homer to the Apostolic Fathers. James Barr's criticism on the ThWNT refers to the implication of Christian ideas in the contextual meanings of the LXX. Emanuel Tov (1976), on the other hand, gave the key for further constructive investigations. He made the distinction "between three different dimensions of lexicographical description: the meaning of the words in the pre-Septuagintal stage, the meaning in the LXX itself as intended by the translators, and the meaning of the words as 
present aspects, which - of course from the perspective of a native speaker - are really able to provide exegetical and hermeneutical useful insights into the lexical and metaphorical meanings of the word in question.

\subsection{Occurrences of ßpotós in the Homeric Epics ${ }^{18}$}

As our brief survey with the assistance of TLG indicates, ßpotós occurs first in the Homeric Epics ( $8^{\text {th }}$ century BC), which had a permanent influence on the word-usages and meanings ${ }^{19}$. In the Homeric Epics, compound nouns and verbs with ßpotós are also

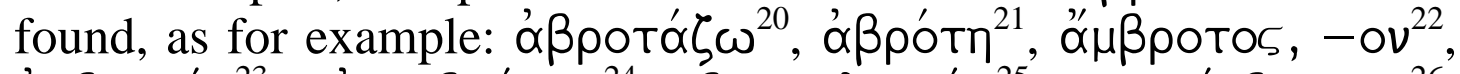

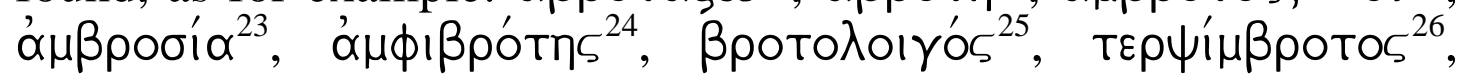

quoted from the LXX. A theological tension can often be found between meanings of words intended by a Greek translator, and meanings attributed to the same words in the New Testament, the Writings of the Church Fathers and in the translations made of the LXX". This distinction is in accordance to Barr's (1961 [1965]) criticism on the ThWNT and against Georg Bertram's attempt to analyse the Septuagint as "preparatio evangelica" (1957), namely to explain Septuagintal terms anachronistically, by putting Christian meanings in Septuagintal words. In my view, this statement could also be understood as a warning to us about the tendency to understand Septuagintal meanings only on the basis of the Ancient Greek linguistic and mental system, especially Platonism; specifically not the works of Plato himself, but the reception of Plato in the Middle Platonism and beyond.

18 Ilias (Il) 1:272; 2:248.285.821; 3:223; 5:304.361.604; 6:142; 7:446; 8:428; 9:159.545; 10:83.386; 11:2; 12:327.383.449; 13:244.374.569; 14:325; $15: 98 ; 18: 85.362 .539 ; 19: 2.22 ; 20: 248.287 ; 21: 380.463 ; 22: 31.76 ; 23: 439$; 24:43.67.363.464.505.525.533.565. Odyssey (Od) 1:32.66.282.337; 2:216; 3:3; 4:78.190.196.197.397.692; 5:2.101.129.197.218.334; 7:119.149.153.160.201. 205; 8:210; 9:16.222.239.487; 10:405; 11:147.218.287.476; 12:77.125.341. 386; 13:129.180.200.297.312.397; 15:253.255.321.343.408.492; 16:63.148. 212; 17:386. 519; 18:85.116; 19:107.170.286.330.360.365. 567; 21:308; 23 : 187.216.267; 24:189.267.

19 Tebben (1994-1998). Snell (1979 \& 1991).

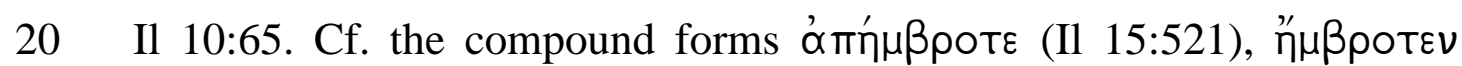

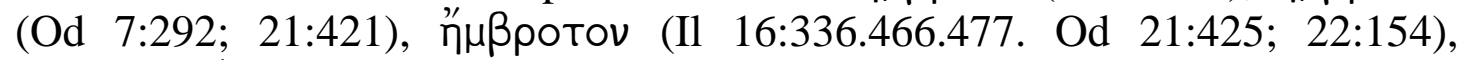
$\beta \varepsilon \beta \rho о \tau \omega \mu \varepsilon v \alpha($ Od 11:41).

21 Il 14:78.

22 Il 5:339.870; 16:867; 17:194.202; 20:358. Od 8:260.265; 11:222; $12: 330 ; 24: 59.445$. 


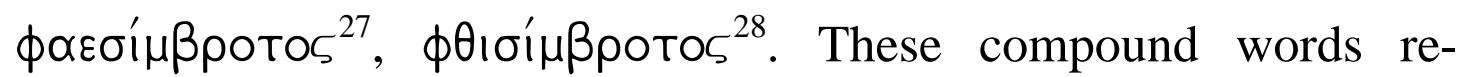
appear with the same meanings in later works of Ancient Greek Literature, mainly as citations of Homer. Of special interest is the noun $\alpha \mu \beta p o \sigma i \alpha$ which designates the food of the immortal gods of the Ancient Greek Pantheon ${ }^{29}$.

Homer makes use of ßpotós both as a substantive and as an adjective. Bрotós as adjective occurs in the word-combination ßpotós ơvin $\rho^{30}$ which obviously makes a distinction between ơvin and his quality (to be ßpotós). As substantive, it appears in word-

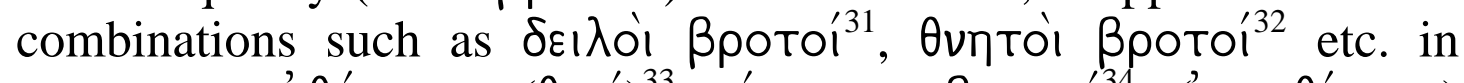

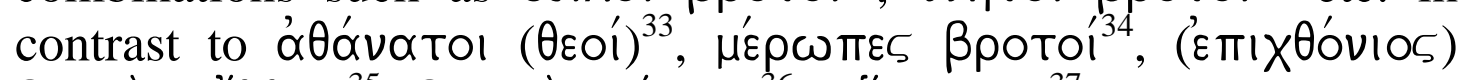

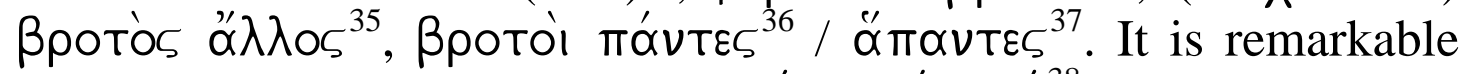
that the contrasting word-pairs $\theta v \eta$ Tó $^{\prime}-\theta \varepsilon \varepsilon^{\prime},-\alpha^{38}$ appear very often in the Homeric Epics ${ }^{39}$, while the word-pair ßpotós-ád'óvơ tos ${ }^{40}$ occurs very rarely in connection with human qualities ${ }^{41}$ and virtues ${ }^{42}$

24 Il 2:389; 12:402; 20:281.

25 Il 5:31.455.518.846.909; 8:349; 11:295; 12:130; 13:298.802; 18:421; 19:9; 20:46; 24:464. Od 8:115.

26 Od 12:269.274.

27 Il 24:785. Od 10:138.191.

28 Il 13:339. Od 23:297.

29 According to Homer, Odysseus on the island of the nymph Calypso, who promised him immortality, ate $\alpha \mu \beta p o \sigma i ́ \alpha$ (Od 5:93.199; 9:359).

$30 \quad$ Il 5:361.604; 18:85; 19:22; 21:380. Od 4:397; 5:129.197; 12:77.341.

31 Il 22:31.76; 24:525. Od 11:19; 14:408; 15:212.

32 Od 3:3; 8:210; 12:386.

33 Od 3:3(=12:386); 5:2f.

34 Il 2:285.

$35 \quad$ Il 3:223; 20:83.386; 24:505. Od 15:321; 19:286; 23:226.

36 Od 19:330.

$37 \quad$ Il 13:374.

38 Il 2:821; 9:159; 24:363.533. Od 1:32.66; 4:397; 5:101.129; 6:149.

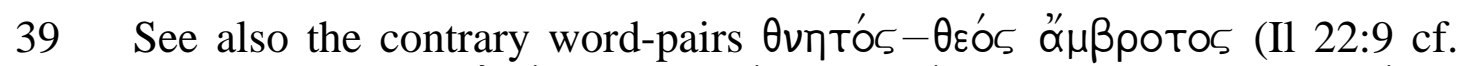

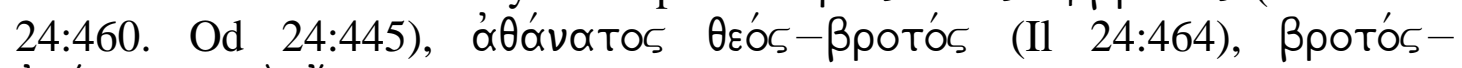

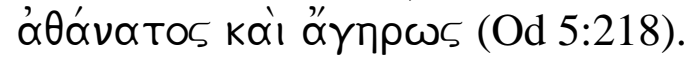

40 Il 11:2; 19:22; 21:380. Od 5:2.

$41 \quad$ E.g. Od 1:337; 6:119s(=13:200s); 13:312. 
already named or described ${ }^{43}$ in the given context. These lexicographical aspects must especially be taken into consideration in the case of a translation critical description of the LXX-Job.

\subsection{Occurrences of $\beta$ potós in the Septuagint-Job}

On closer examination, we realize that $\beta$ potós appears parallel to

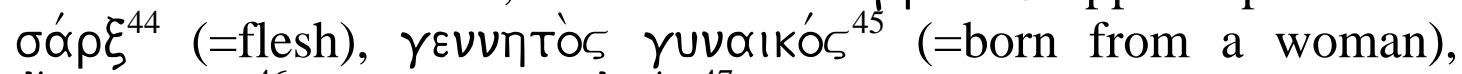

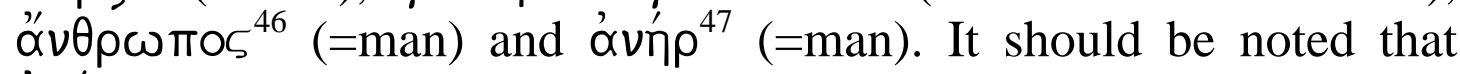
ơv' $\rho$ in these specific cases does not designate gender, but positive qualities of a man ${ }^{48}$ that can also be ascribed to women under certain conditions. Therefore, further examination has to focus on linguistic as well as factual components of the given texts.

\subsection{Etymology - Meaning - Translation}

1. An important distinction, which should be taken into account when analysing and describing the theological and anthropological sense of ßpotós, is between original and secondary meanings. The original meaning could also be derived from the word-etymology, because it may be included in the word itself, if the word has been artificially created by an author to serve certain purposes. In this case, secondary meanings have to be the prevailing themes and ideas of each context where the word is embedded. The word Bpotós probably has been formed on the basis of already existing linguistic resources. Therefore, one should constantly pay attention to the linguistic aspects of the lexical equations of the Hebrew and Greek language.

Two kinds of hypotheses with regard to the relationship between the etymology and semantics of ßpotós had already been developed in antiquity:

a) Aelius Herodianus (Pseudoherodianus) (2nd century AD)

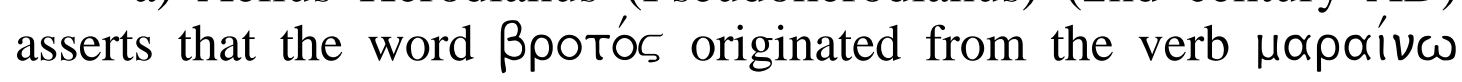

$42 \quad$ E.g. Od 8:239; 13:297.

43 E.g. Od 4:692; 8:487.

44 Job 34:15.

45 Job 11:12; 14:1; 15:14; 25:4.

46 Job 10:4; 11:12; 28:13; 32:21; 36:25.

47 Job 4:17; 14:10.

48 Cf. Matthäa Vock (1928). 


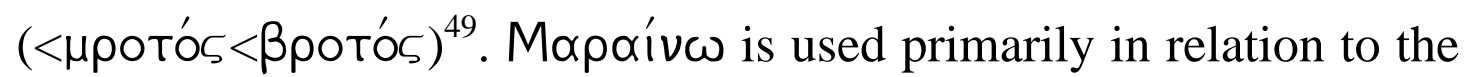
plant kingdom in order to designate the withering of flowers and leaves $^{50}$. In this instance, we can state that the word Bporós semantically derives from the plant kingdom and has become a symbol for man as an individual and for mankind in its entirety.

b) Hesychius (5th/6th century AD), who established the Ancient Greek word-meaning in the form of a dictionary, made a distinction between the substantive ßрótos and the substantivated adjective $\beta$ potós (postponement of the accent) ${ }^{51}$. According to Hesychius, ßрótos is a primary name designating both blood as well as an infection through blood. He supports this hypothesis with text evidence from Odyssey and Ilias ${ }^{52}$, and equates $\beta$ porós with the

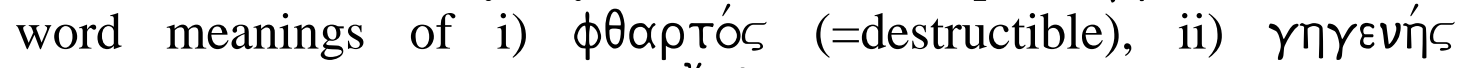
(=coming from earth) and iii) ơv 0 p meanings are not completely congruent but flow into one another.

Furthermore, there are two Greek verbal-adjectives, which can

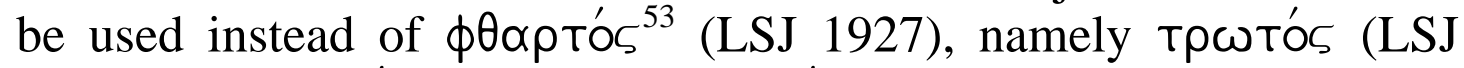

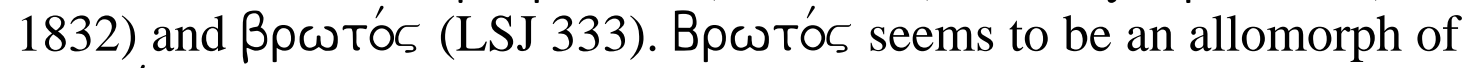
ßpotós, and in the text-transmission of the hymns of the Ancient

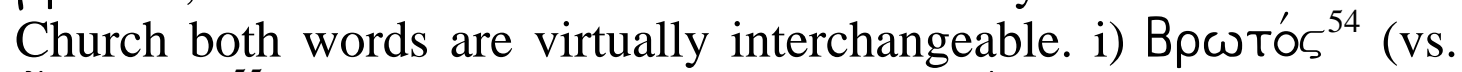

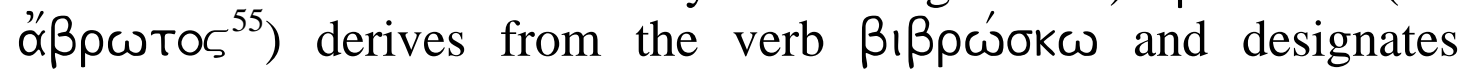
"something to eat, to distort", and in metaphorical sense "to rot, to decompose", as well as "the decomposed human flesh" (LXX-Job

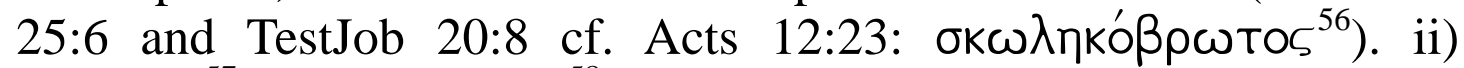

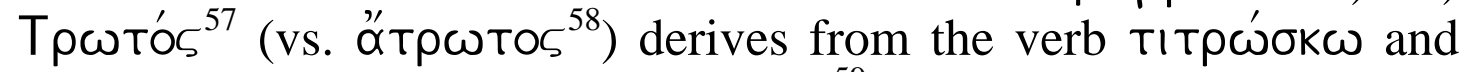
designates the wounded or injured $\operatorname{man}^{59}$.

49 De Prosodia Catholica, 3,1.124,14; 3,2.288.25.

50 Sir 14:18 cf. Il 6:146-149.

51 Hesychii Alexandrini (MCMLIII-XVI:349).

52 Il 7:425; 14:7; 18:345; 23:41. Od 24:189.

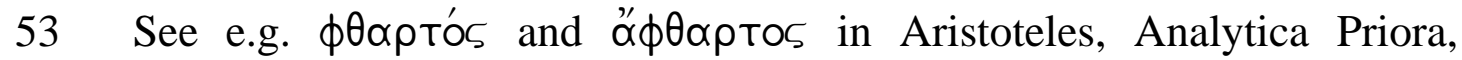
47b:25.29; 49a:24; 68a:9.10.16 etc.

54 Euripides, Supplices 1110. Theophrastus, Historia plantarum 1.12.4.10 etc.

55 Aristoteles, Historia animalium 505b:20. Meteorologica 380b:3.

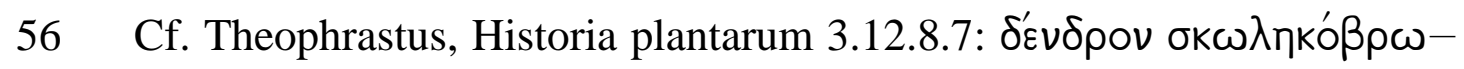
Tov.

57 Il 21:568. Euripides, Helena 810. 
Using a scale of meaning in order to indicate various meanings of the words, we can establish the following scheme:

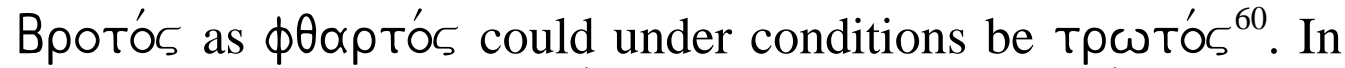
this case, the meaning of ßpotós is the same as $\beta p \omega t o ́ s$, namely "decomposeable". But on the other hand, if the word-meaning handed down through Hesychius is right, then ßpotós could be used as a designation of "blood" as the Sitz im Leben (setting of life), and thereupon as a characterisation of a living human being. Consequently, the word-spectrum of ßpotós could contain both biological as well as ethical-moral meanings. Behind this wordusage may be hidden the ancient idea of a connection between the blood and the moral-ethical disposition of every human being.

In current language usage, blood can designate not only life, but also death, through its infection. This could be the biological explanation of the word Bpotós. However, there is not only a biochemical infection, but also a moral infection of blood as setting of life ${ }^{61}$ e.g. through lies which cause unjust and unfair deeds.

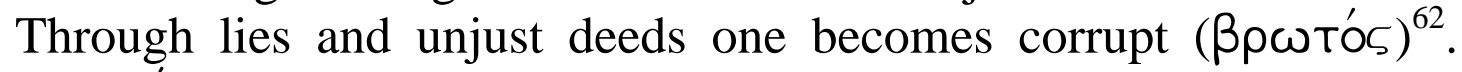
Tpwtós, in this case, is the person who leans over to let himself be guided by lies and governed by injustice and unfairness ${ }^{63}$. $00 \propto \rho$ Tós, on the other hand, indicates destructive urge, moral offence or misdemeanour and destructive deeds ${ }^{64}$.

2. Through the prefix-negation $\alpha^{\prime \prime}-$ the adjective $\alpha^{\prime \prime} \mu \beta$ potos is formed. This word has been used to describe the divine nature in contrast to the human. Greek gods are $\alpha^{\prime} \mu \beta \rho о \tau o$ and eat $\alpha \mu \beta \rho \circ \sigma^{\prime} \alpha$, while man is ßротós, but can also be characterized as про́ßротог.

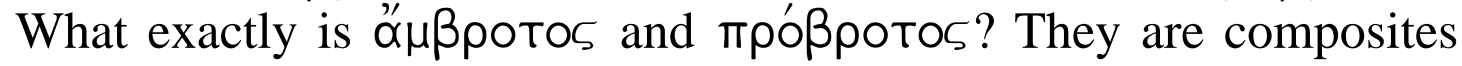

58 Pindarus, Isthmia 3/4 18b. Aeschylus, Choephoroe 532. Euripides Phoenissae 594. Sophocles Oedipus Coloneus 906 etc.

59 Il 21:568. Cf. öтрwто5 in Euripides, Helene 810. Phoenisae 594. Fragmenta Alexandri 43,30, as well as Fragmenta 9d.34.

60 LXX-Job 6:9; 16:(6)7; 20:24; 33:23; 36:14; 36:25; 41:19(20).

61 Cf. Kedar-Kopfstein (1977:248-266). Cf. G Gerleman (1971:448-451).

62 Cf. Stephanus Medicus et Philosophus, Scholia in Hippocratis de Fracuris 79,17s.

632 Macc 3:16.

64 Cf. LXX-Isa 54:17. Wis 9:15; 14:8. 2 Macc 7:16. LXX-Gen 6:11. Ex 10:15. Isa 24:3.4. 
made by putting together the main word ßpotós and the proelements $\alpha^{\prime \prime}-$ (in-, un-) and $\pi \rho o_{-}-$(pre-). It is noteworthy that both composites indicate human depictions of the divine nature. This means that man, through self-observation, forms his divine pictures and ideas. According to Diogenes Laertius ( ${ }^{\text {rd }}$ century AD), a human being can be characterized as mрóßрото - if it had not existed yet, namely before birth: ôs $\delta$ ótร oú $\delta^{\prime} \nu^{65}$. According to Hesychius, the adjective $\propto$ $\mu \beta$ poros can only signify divine nature. On the basis of the written evidence, we are not able to establish whether he really identifies $\alpha \mu \beta$ poros with $\alpha \gamma^{\prime} \varepsilon \nu \nu \eta T o s$ or not. Of course, theogonies are handed down through the centuries. The

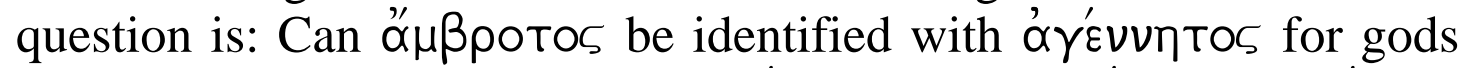
and stand in opposition to ßpotós and revvitós ruvaı́ós, a favourite term of the book of Job? Inasmuch as the gods of the Greek Pantheon are not born from a woman, they can also be characterized as å $\gamma^{\prime} \varepsilon \nu \nu \eta T o$, but not without exceptions. In this

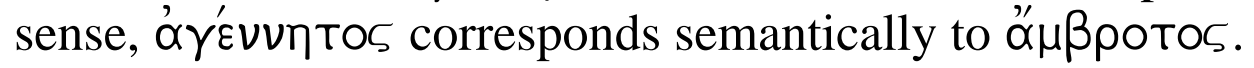

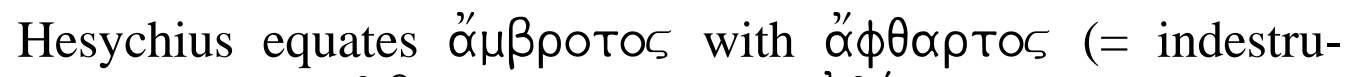

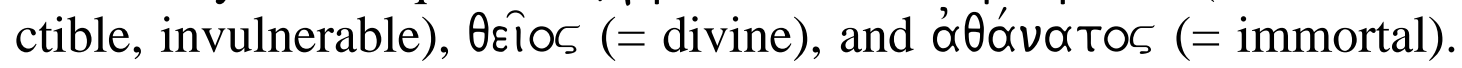
We here can find the justification of the modern semantic equation

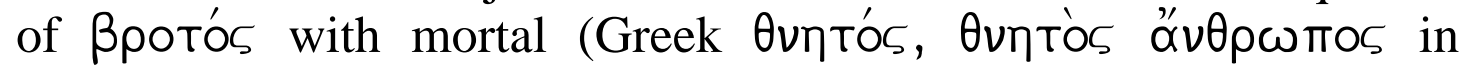
opposition to the divine adjective $\alpha \theta$ óvatos). The equation in

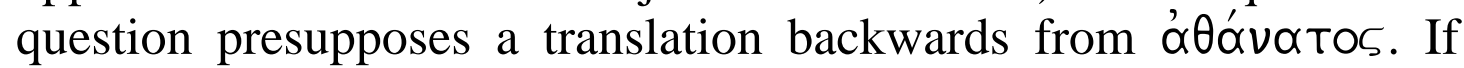
ßpotós could be derived from $\beta ı \beta \rho \omega ́ \sigma \kappa \omega$, then their wordmeanings were the same, as claimed by Hesychius. But if ßpótos simply means blood, it indicates the setting of life, while ßpotós designates living human beings. Of course, "mortality" belongs to the meaning of the term "man, human being", but "mortality" must not be necessarily seen as the main meaning of ßpotós. In this case, we must take the following factors into consideration:

\section{i) Bротós, aîu and ßpótos}

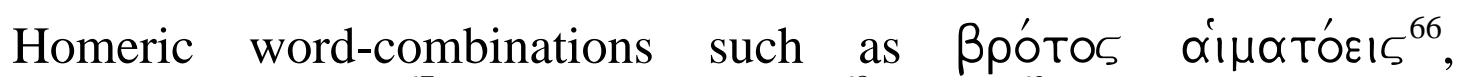

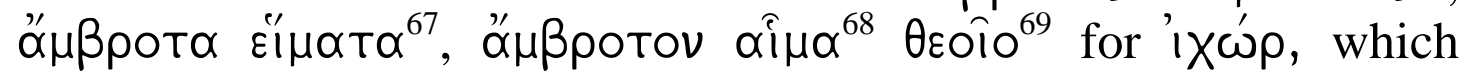

65 Diogenes Laertius, Vitae Philosophorum, VIII 45.4.

66 Il 3:345; 7:425; 14:7; 17:345; 23:41. Od 24:189.

67 Il 15:670.680. Od 7:265; 24:59.

68 Il 5:870.

69 Il 5:339.870. 
establish a connection between ßpótos (= blood) ${ }^{70}$ and ßpotós, lead to the question: are they tautologies? Has ßpotós really derived from ßрótos, or should we assume another word-origin and, therefore, other word-meanings? Is the derivation from $\beta$ ı $\beta \omega \sigma k \omega$ conceivable or should we assume Semitic origins? Does the Hebrew בשר form the basis of the Greek formation ßpotós, or do both words, the Greek Bpotos and the Hebrew בשר, follow the same Semitic archetype, but with virtual consonantal variations?

It is typical in Homeric texts that Bpotós and oiju are not semantically connected, but both of them appear in war scenes. Thus I intend to consider Bpotós as a derivative of the Greek verb

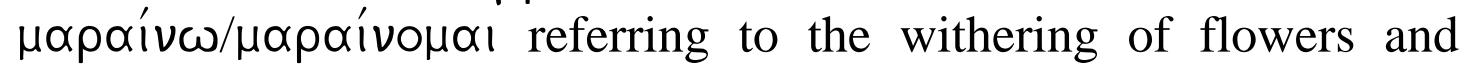
leaves. This word-origin has been assumed by ancient grammarians and has pragmatic consequences for the interpretation of the context in which the word is embedded. If blood is really the place of the life of every living being, man or animal, then water can also be seen as the place of the life for plants. Therefore, if the designation $\beta$ potós has been used for human beings, the image of man can be metaphorically associated with blossom- and flower-images connected to vital questions regarding the human existence. A flower is not a thorn used as a symbol for suffering. It symbolizes beauty and boldness, but also transience and transitoriness. The withering of a flower is not the end of life, but the beginning of a new life. From a blossom comes seeds, and from seeds new plants, and from plants spring up new flowers.

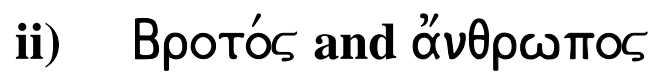

Aristotle (384-322 BC) puts the well-founded question, do ßpotós and $\alpha$ ' $v \theta \rho \omega \pi$ os have exactly the same meaning or not. The response is developed in a philosophical definition of both terms in his Topica 133a:32ss:

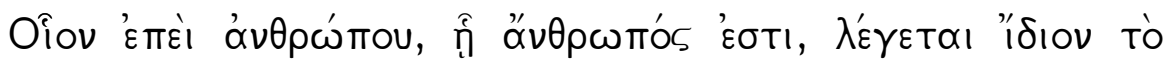

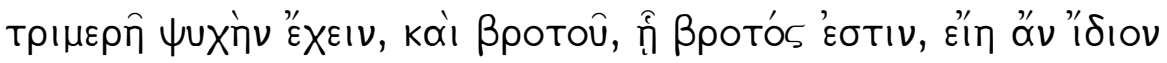

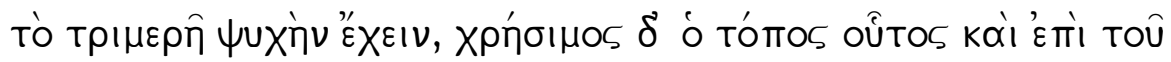

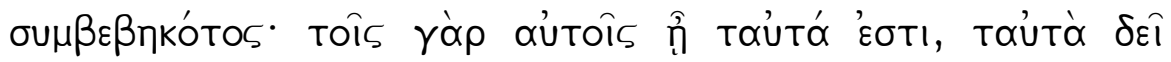

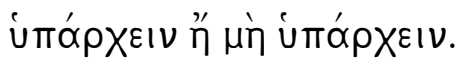

LSJ 331: "blood that has run from a wound, gore”. 
The Aristotelian definition gives the word a new coinage in stricter connection with the triune nature of the human soul, as already discussed by Plato. This coinage goes beyond the lexical meaning and allows for a new interpretation of Bpotós - in contrast to the occurrences of Avntós in Biblical writings. Bpotós is definitely not identical with $\theta v \eta$ Tós, but with ơ $v \theta \rho \omega \pi \%$. If the etymological definition of $\alpha$ ' $v \theta \rho \omega \pi \% 5\left(\alpha^{\prime} v \omega+\theta \rho \omega \sigma k \omega=\right.$ he who is orientated towards the heaven) which is derived from Ancient Greek oral traditions and ascribed to Basilius the Great, a student of Ancient Greek authors in Athens, is correct, then ßpotós is man who is not delivered to death, but to eternal life. Thus, we can understand why the Septuagint translators of the Hebrew Scriptures avoided Ovntós ${ }^{71}$ as an equivalent for the Hebrew

What is the reason for the English translation of ßpotós into mortal and the German translation into sterblich? Are English translations simply depended on the German? Is there no exact English or German equivalent with identical fields of meaning? Did the English or German translators use a fairly similar equivalent, having missed the real sense of ßpotós? Later borrowers of these translations probably have not been aware of this problem. Therefore, we have to leave the issue of finding a better equivalent in the hands of competent English or German philologists.

\section{HOMER'S ODYSSEY AND THE SEPTUAGINT VERSION OF JOB}

\subsection{Similarities and dissimilarities: some fundamental considerations}

In discussing the contextual meaning and sense of Bpotós in Homer's Odyssey and LXX-Job ${ }^{72}$ it may be helpful to begin with a few comments about the literary and ideological context in which the word is embedded. It is not my intention to provide a full

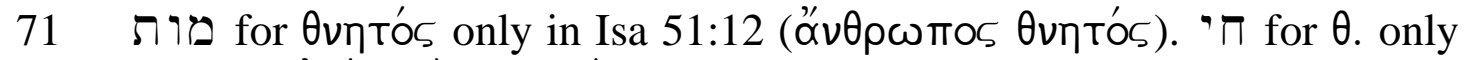

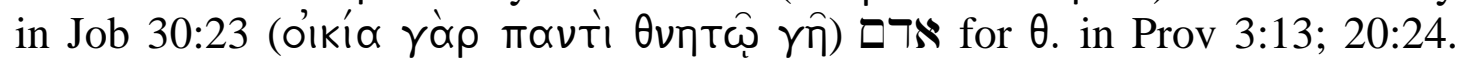
Further Wis 7:1; 9:14; 15:17. 2 Macc 9:12. 3 Macc 3:29.

72 General features about the relationship between Homer and Old Testament, but without regard to the LXX, see Gordon (1955:43-108). On the Jewish reception of the Homeric epics in the Hellenistic Era see Dafni (2006b:34-54). 
explanation of all possible convergences or divergences, but to outline only those points which are significant for the present study.

1) Both works, Homer's Odyssey and the book of Job, are poetical compositions which have undergone long processes of linguistic and mental refinement and canonical standardization. Their complex plots, consisting of heavenly and earthly events from divine and human perspective, revolve around a common ideological centre, namely the issue of theodicy ${ }^{73}$ as an attempt to explain, in a reasonable manner, the relationship between human suffering and divine justice.

2) The beginning of each work is about a heavenly assembly and the special qualities attributed to both protagonists, Odysseus and Job.

a) Within the framework of the Homeric anthropomorphism, attention is paid to Odysseus' similarity to the gods (Od 1:65s: $\theta \varepsilon i 0105^{74}$ ) with regard to particular sacred actions.

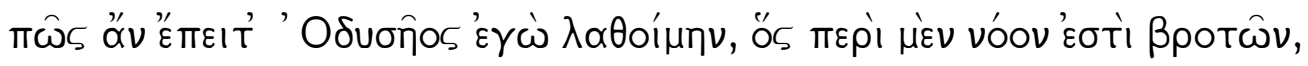

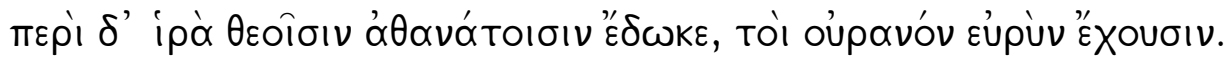

b) In accordance with Old Testament monotheism, the Jobnarrator says that God considers Job an incomparable ethicalmoral person (Job 1:8 parall. 2:3):

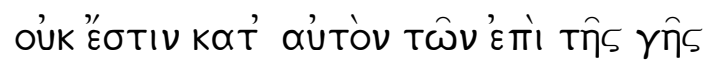

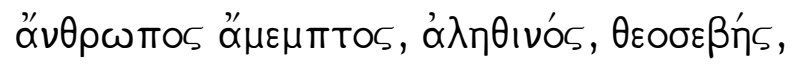

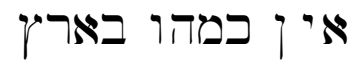

איש תם וישר ירא אלהים

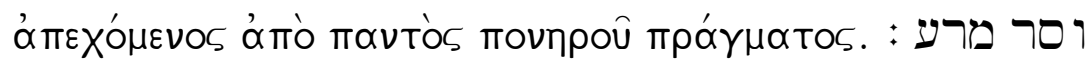

The MT talks about " $a$ perfect and upright man, fearing God and turning away from evil", " while the LXX-interpretation offers: " $a$ man blameless, true, godly, abstaining from everything evil",76, and despite tests "still clings to his perfection" (2:8).

3) Both Odysseus and Job must suffer. Thus, the question we have to ask is: what causes human suffering; particularly if he who suffers is indeed (or, at least, seemingly) righteous? The question as well as its

73 See Leibnitz (1744).

74 Od 1:65; 2:233.394; 3:398.417; 4:682.799; 5:11.198; 15:63.313.347.554;

$16: 53 ; 17: 230.402 ; 20: 248.283 .298 .325 ; 21: 74.189 .432 ; 24: 51$.

75 Dhorme (1967:6.15s.).

76 Brenton ([1844] 1976: 665s). 
answer, was developed in the prologues of both literary compositions.

a) The prologue of the Odyssey is about the assembly of the Olympian gods. In this assembly the suffering of Odysseus is assessed retrospectively and decided at the time of his homecoming.

b) The prologue of the book of Job, on the other hand, is about the heavenly assembly of God. In this assembly, Satan appears, and, as the result of his intervention, God permits the misfortunes and trials regarding Job's property, family and body.

4) In surveying these prologues, one is struck by two facts: Job is completely innocent; Odysseus, however, must suffer on account of his companions. Human hubris causing death is described in the Odyssey as follows: The companions of Odysseus, despite warnings, sacrificed and ate the cattle of Helios, and thereby committed an outrage. Because of this outrage they had to be destroyed ( $\mathrm{Od} 1: 7 \mathrm{~s}$.), but Odysseus alone survived. Odysseus dazzled the Cyclops Polyphemos, the son of Poseidon, who had already eaten two of his comrades, and wanted to kill and eat all of them. This is why Poseidon, the father of Polyphemos, prosecuted Odysseus and why Odysseus had to suffer under Poseidon's merciless wrath (Od 1:20s.). But Job suffers while resisting Satan's temptation and withstanding all his misfortunes and trials (Job 1:21; 2:10). Odysseus overcomes Poseidon's terrible blows through the helpful intervention of Athena and his own inventive intelligence. Job fights against the attacks of Satan with patience and unshakable trust in God, although God did not give a sign of His helpful guidance and protection.

5) Essential for a proper understanding of the theodicy in Odyssey and Job is the fact that various approaches converge into contexts using Bpotós with regard to the fundamental question about the relationship between human suffering and divine righteousness.

a) In the Odyssey (1:32ss), Zeus himself formulates the problem of theodicy as follows:

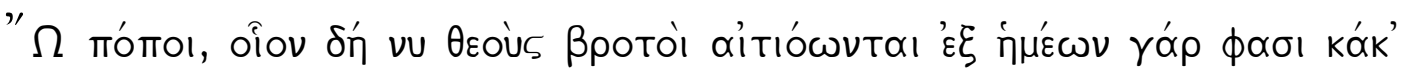

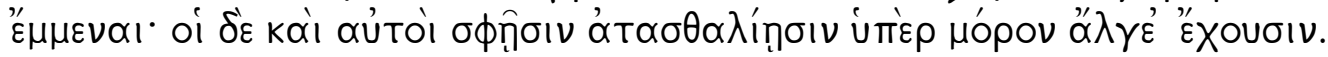

b) In the book of Job we can establish two different ways of looking at the theodicy-problem: The divine perspective in the 


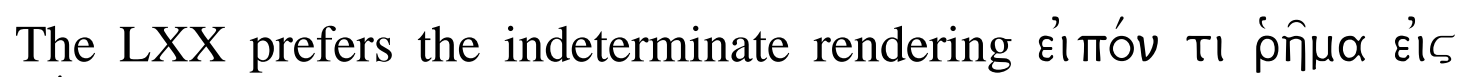
Kúpıov and dispels the suspicion that the woman once again acts as an instrumentum diaboli. This rendering must be understood as the sequel to a large LXX addition concerning the lamentation of Job's wife explaining her own suffering, which will be discussed in more detail in another article.

Job's response in interrogative form (Job 2:10) does not deviate from his initial position (Job 1:21):

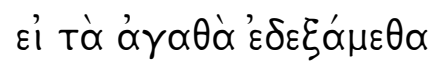

Ek XEıрòs Kupíou,

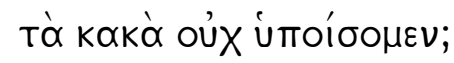

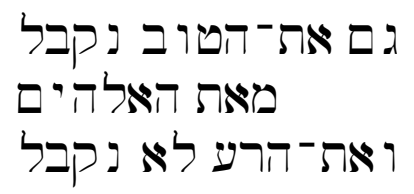

The LXX version seeks to avoid the suspicion that evil as well as good is caused by God and prefers the explanation ' $\varepsilon$ K $X \varepsilon 1 \rho{ }^{\prime}$ Kupiou (= from the hand of the Lord) instead of the Hebrew מאת הארדיםי (= from Elohim). This rendering is used to mark clearly cause and permission of evil with a strong emphasis on an intermediary between God and man, represented by Satan, as an unexpected visitor to God's heavenly assembly.

\subsection{The poetical parts of Job}

From another viewpoint and on a much narrower textual basis, the later poetical parts come closer to the problem of the theodicy. The poetical parts invoke a repeated expression, in the way of a refrain, spoken by a "night figure", Job and his friends. This expression can be seen as reminiscent of the above-mentioned aphorism of Zeus (Od 1:65s).

1) In Job 4:17 we read in the LXX:

Tí róp;

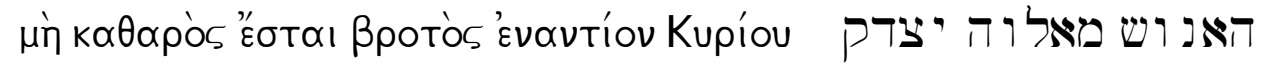

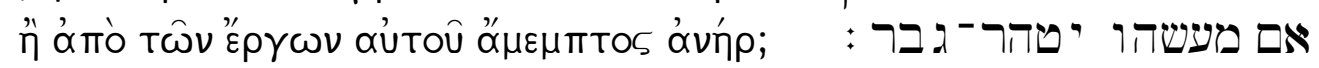

The question of the "night figure" according to the MT places emphasis on the reason that nobody can claim to be righteous and

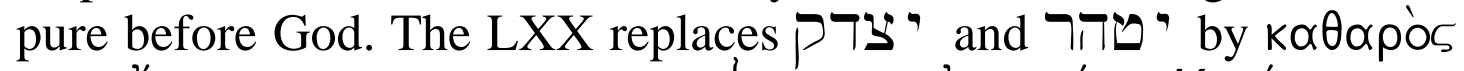

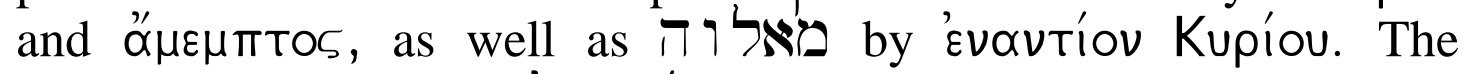
ambiguous preposition 'Evavtiov accentuates not only that every human being stands before God, a declaration of God's omnipresence, but also the fact that under certain conditions human beings can revolt against Him ('Evavtíov Kupíou). These conditions have already been explained in Job's prologue. The adjective 


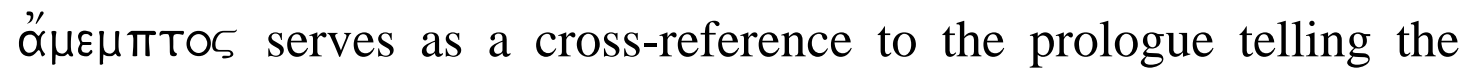
reader to again look at Job's attributes as awarded by God and to remember that Job had never designated himself to be righteous before God. This fact gives the impression that the words of Eliphaz got inspired, not by God, but by Satan. In this way, the translator shows clearly the logical connection between the prosaic and poetic parts of the book.

2) In Job 9:2, we read in Job's monologue:

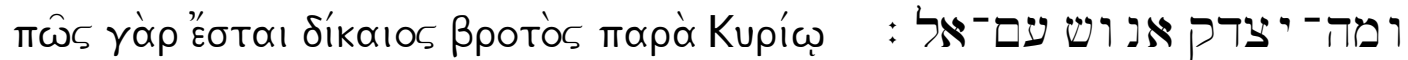

In this more literal translation, special significance is given to the limitations of the human nature in spite of righteousness ( $\pi \hat{\omega} s$ and mapó Kupíw "how" and "with/by God"). In Job 4:17, the opposition between God and man is emphasized; Job's words evoke a feeling of human belonging to God, but underline the difference despite closeness between God and man.

3) In Job 15:14 the question is:

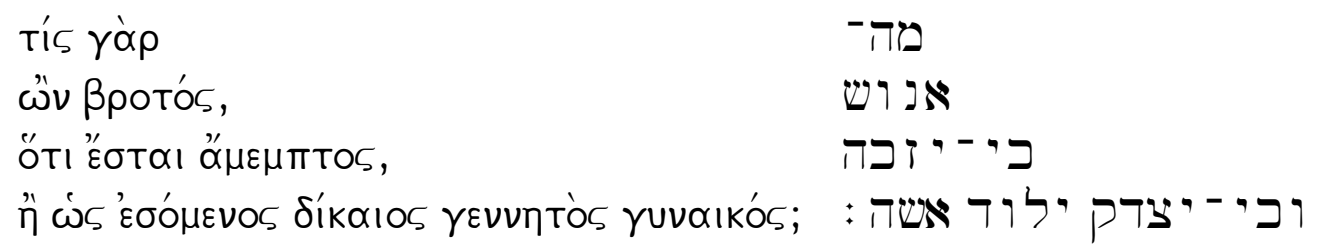

The Hebrew elliptical interrogative clause מהידאנ ושי is followed by two subordinated $\supset$-clauses. In the Greek translation we find a

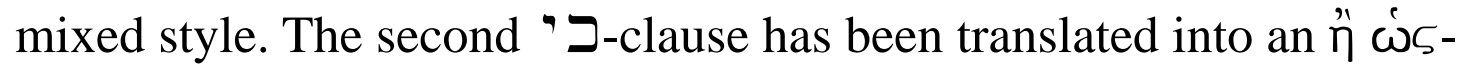
clause alluding briefly to the role of Eve in Adam's sin (according to Gen 2-3). LXX-Job 15:14 provides the contrary, referring to human

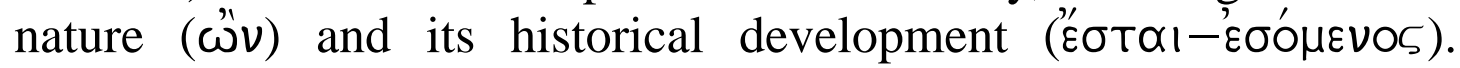
Accordingly, human nature is decisive for only limited possibilities

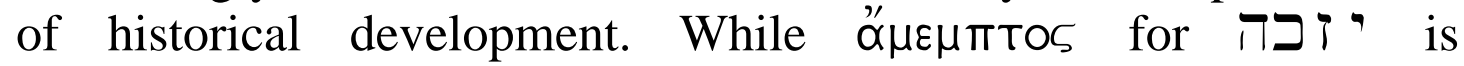
reminiscent of LXX-Job 4:17 and the attributes awarded to Job by

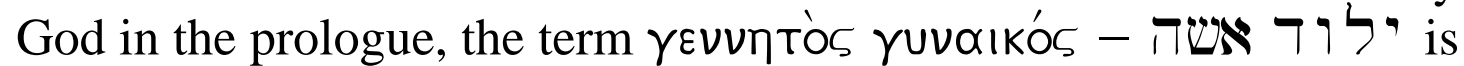
used parallel to ßpotós as a cross-reference to Gen 3:14ss. In connection with díkalos $-\boldsymbol{P}^{י}$, the term in question recalls the violation of the divine commandment "not to eat of the tree of the knowledge of good and evil". But Adam and Eve refuse to obey God and follow the godless will of the serpent, as well as their own desires. 
4) LXX-Job 25:4 says:

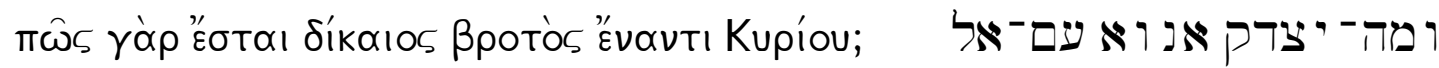

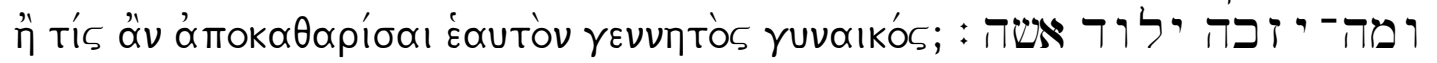

It is not simply a repetition of LXX-Job 15:14 but its completion, because it contemplates reconciliation between God and man through human purification. The question of whether or not human beings can purify themselves implies dependence on God's forgiveness and redemption.

5) Job 10:4a shows that the word choice in the LXX is not arbitrary.

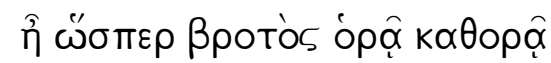

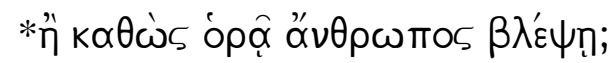

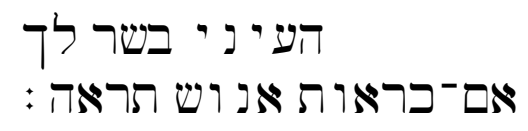

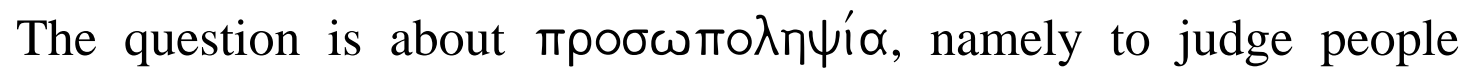
according to their outer image and not according to their heart. This issue has been explained in TestJob 4:8, where a "night figure" tells Job that God judges and repays not according to the "outer image"

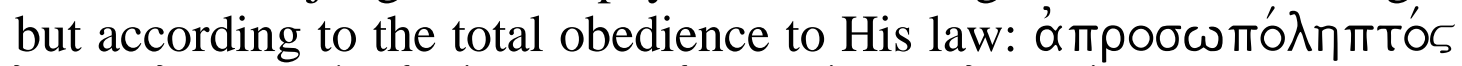

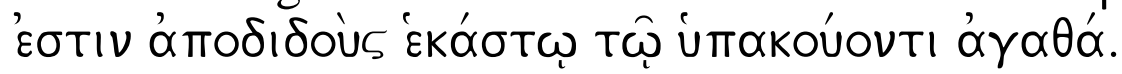

It is noteworthy that this is the only case where ßpotós replaces בששר. Although in the same context of God's judgement the

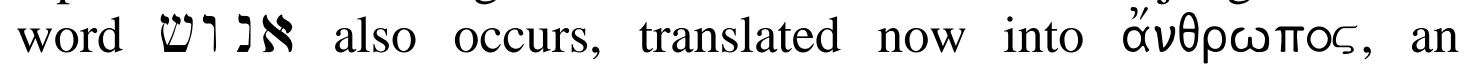
equivalent also determined by Aristotle (Topica 133a:32). In this sense, it could be considered as a sign of interchange between

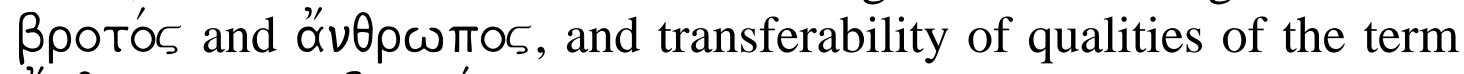

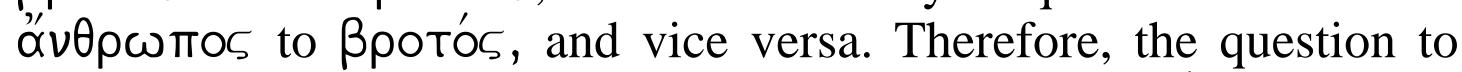
ask is what kind of new coinages does the term ßpotós receive in the Job-poetry? Apart from this it is also necessary to prove, on the basis of text examples, if we are able to progress from the word etymology to text ideology and theology. For this purpose, it is useful to look closer at Job 4:17 and its parallels in the book of Job.

\section{CONTEXTUAL DEFINITIONS OF BPOTO $\Sigma$ IN JOB 4:17 AND PARALLELS}

Both the author and the translator of the book of Job were influenced by Greek ways of thinking and were concerned about giving theologically well-founded short descriptive definitions of the attributes of ßpotós in the context in which this term is used. These definitions must be first identified and the relationship between their components analysed in order to establish the specific theological meaning of ßpotós in the LXX-Job. 
1. The first definition is given in the context of Job 4:17. Job 4:6-7 and 4:12-21 play a decisive role in the understanding of this verse. Eliphaz wants Job to accept God's challenge and to examine whether he, in his everyday life, has ever justified God's punishment (Job 4:6-7). He does not even think about an external, personal cause of evil. His main question is: What does God's justice really mean? Eliphaz seems to understand the Ancient Oriental jus talionis quite literally and is convinced that injustice is automatically ${ }^{77}$ followed by punishment: "Whatever someone sows, that is what he will reap" (Gl 6:7). After that he generalizes this opinion and tries to support it with the description of a dream (see above the original texts). The figure in the dream asks (4:17): MT: "Can a man seem upright to God, would anybody seem pure in the presence of his Maker?" LXX: "What, shall a BROTOS (Brenton: a mortal) be pure before the Lord? or a man be blameless in regard to his works?" The terms

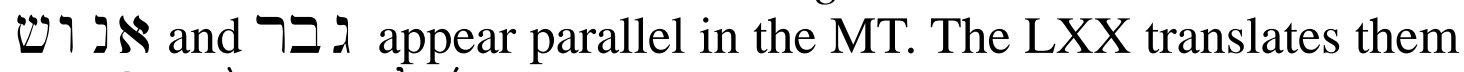
into ßpotós and óv'np. In the Hebrew text a general term, while ג ג has a special meaning. As a designation of God the rare poetical term אל מיד is used, translated in the LXX into $\theta \varepsilon$ 's, referring to God as the Creator of all the world. LXX-Job 4:17 entails two main components: a) the relationship of man (ßрото́s) to the Lord of the whole world (kúpios) ${ }^{78}$, characterized by the adjective $k \alpha \theta \alpha \rho o s$ (=pure) and b) the deeds of a man (ßpotós) and his relationship to his created environment, chara-

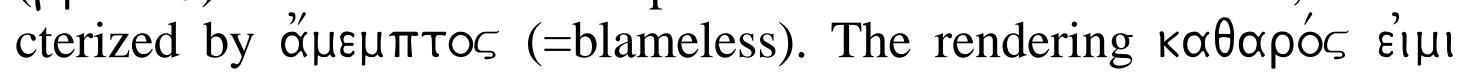
for the Hebrew verbal form צ' is used only once in the LXX.

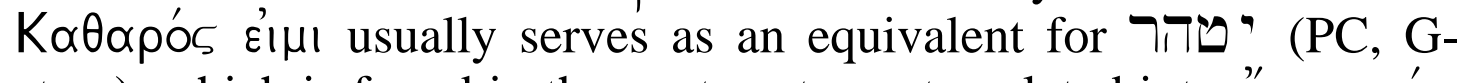
stem), which is found in the next sentence translated into ơ $\mu \varepsilon \mu \pi \tau$ rós

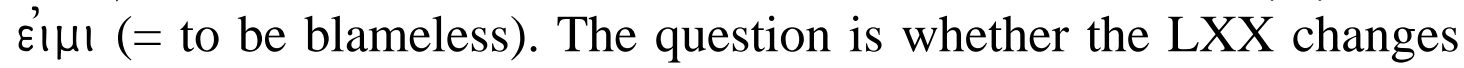
the verse ordering because of poetical freedom, or does it translate a source text with another verse ordering. In this instance, both textual intention as well as the contextual term definition of against ßpotós and ơv'́p change. The relationship of אנפ אלוד is determined on the basis of divine justice, while the relationship of גבר מעשהו as to his Creator is characterized in terms of human purity.

77 Cf. Koch (1972).

78 אלוד for kúplos occurs in Job 3:4; 4:9,17; 5:17; 6:4.8; 10:2; 11:5,6,7; 12:6; 15:8; 16:20,21; 19:6,21,26; 22:26; 27:3,8; 31:6,33. 
Eliphaz and the "night figure" share the same opinion, but their statements of justification are different. Eliphaz' is grounded in human deeds and God's reaction. The "night figure", however, presupposes the general characteristics of human nature in comparison to the attributes of God the Creator, and emphasizes that no human being is righteous and pure before God. Complete righteousness and purity can only be considered as divine attributes, while human beings are marked with inherent imperfection in relation to God and are full of flaws dividing one from the other and from God.

2. LXX-Job 4:19ss provides further examples by which we can gain a sense of the Septuagint connotations of $\beta$ potós.

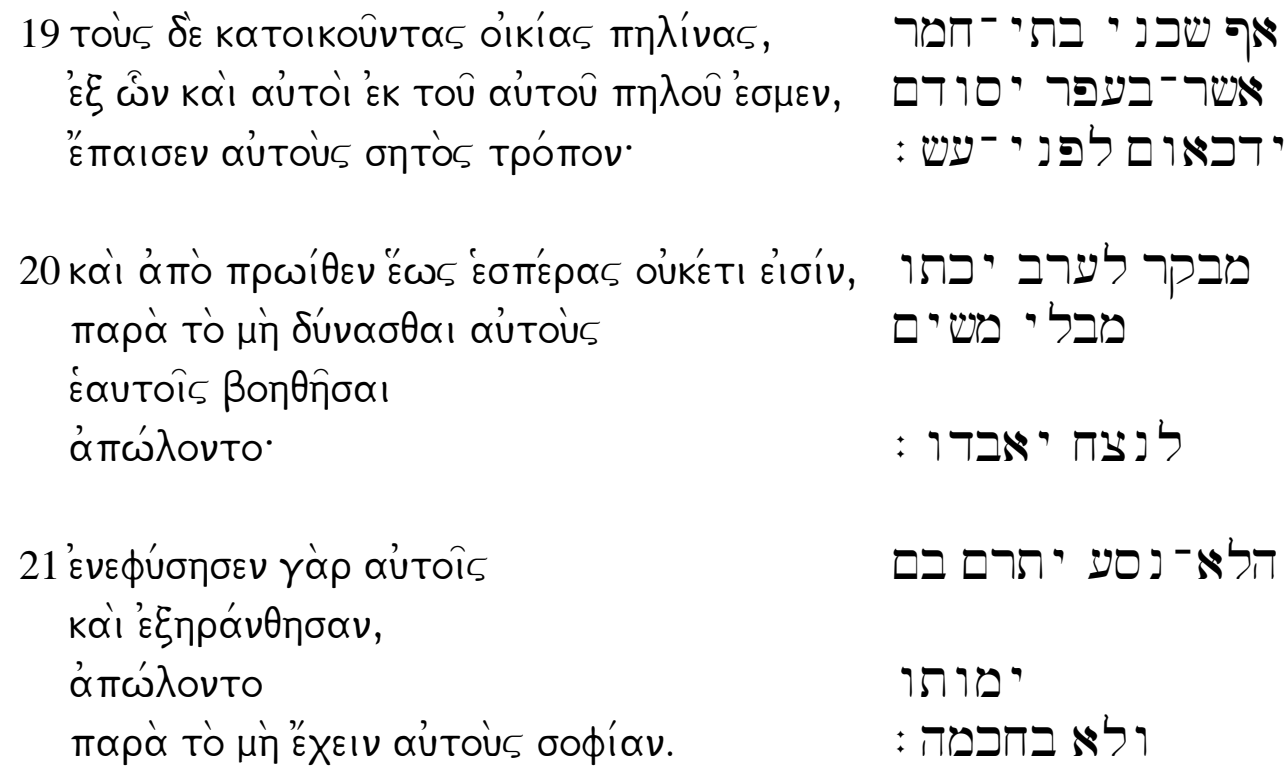

Bpotós is not only he who dwells in a clay hut, but he whose body is formed of clay (cf. LXX-Job 10:9). The MT underlines that all his foundation and support is nothing but clay. Likewise, Gen 2:7 says that human beings are formed of dust from the ground (האדמה) and Gen 3:19 adds that a man is dust and to dust he will

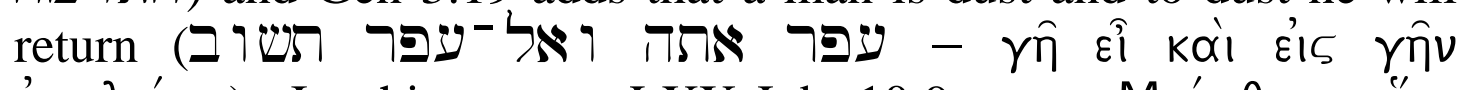

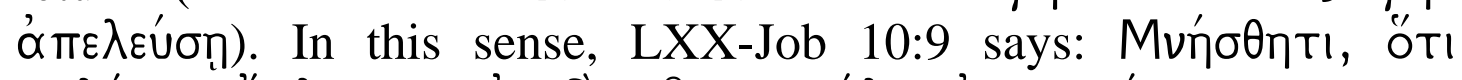

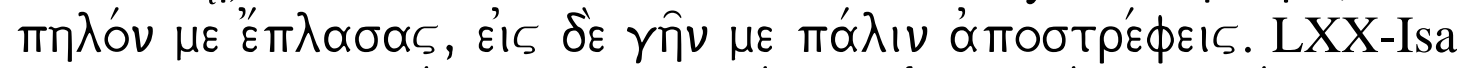

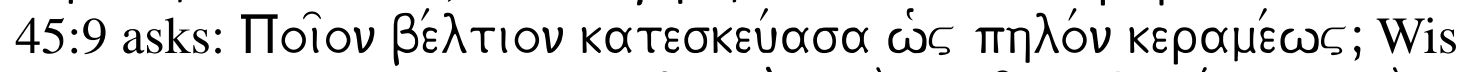

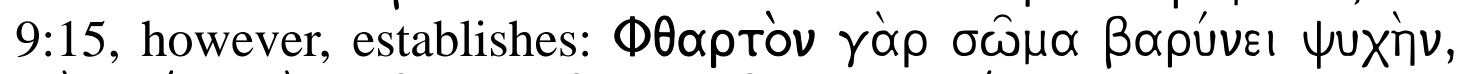

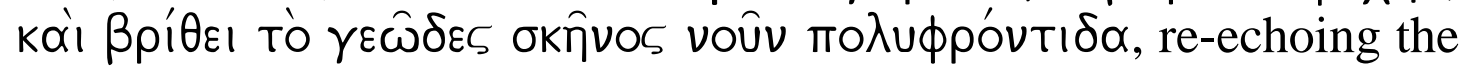
main theological intention of the just mentioned proto-canonical passages. Obviously, the Job-expression maintains close links to Genesis 2:7; 3:19 and Isaiah 45:9. The translator, when using 
חמר חמר, joins terminology and ideology of LXX-Genesis and LXX-Isaiah in one sole expression of LXX-Job 4:19, which

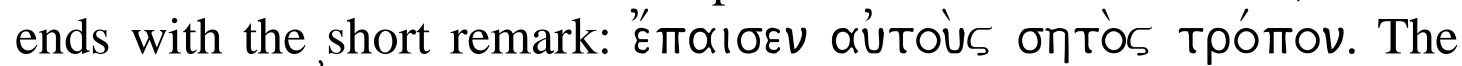

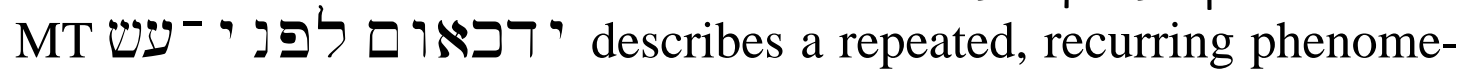
non by means of an imperfect, namely that all human beings will one day be food for the worms, like the flowers will be smitten by a moth. In contrast, the LXX presents a unique event: He smote the ßротоí like a moth. The question is: Who is he? God or Satan? The formulation can be seen as a hint about the role of the serpent in the life of mankind and God's punishment according to Genesis 3. The translator obviously keeps in mind that the life of Bpotos in the context of LXX-Job is comparable to plants (see also LXX-Job 4:21) and not to animals, and therefore compares he who has smitten Bpotós, not with a serpent, but with a moth. The consequences are י בתו י מבקר לערב. LXX-Job 4:20 prefers the philosophical expression „OUK'́t। ĖoIV“ (= they no longer exist), which also recalls the imagery of flowers in blossom for only one day. The reasoning

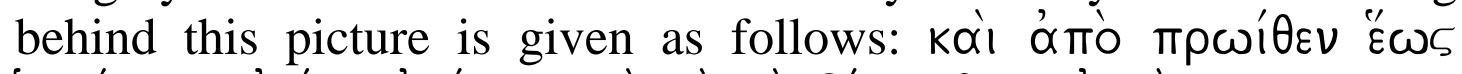

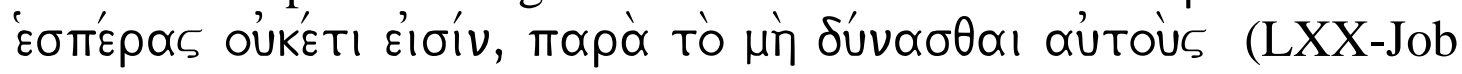
4:20 cf. 25:4). This is explained in the LXX with the imagery from the plant-kingdom: For he blew upon them, and they are withered

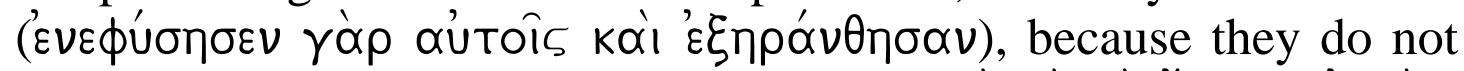

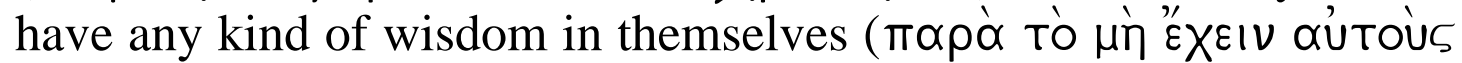
бoфi $\alpha v)$. In this way, the LXX transforms Genesis 2:9 leaving two kinds of interpretation open: God's breath of life upon man's face also means the gift of wisdom. Human beings prefer, however, knowledge of good and evil more than divine wisdom and, therefore, they die. The MT does not only talk about a lack of wisdom (4:21), but also about the lack of a saviour (4:20). Because of its clearly messianic character, this text has often been omitted in the critical

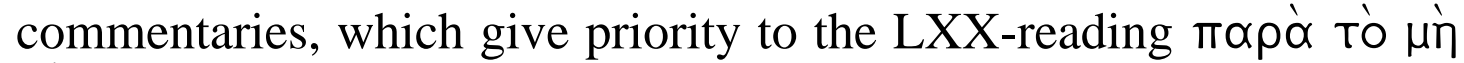

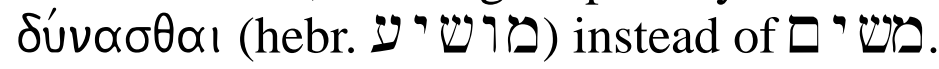

3. The experience of evil in the world and misfortunes in the personal life leads Job to put the question about the lines marking the beginning and the end of ßpotós (Job 10:18-22): 


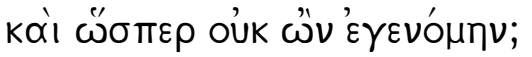

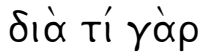

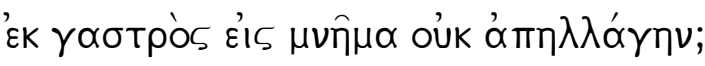

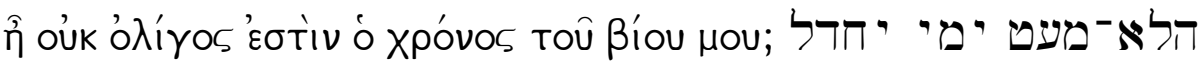

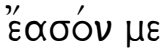

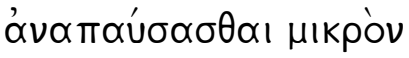

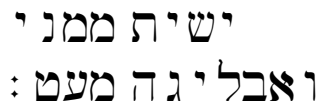

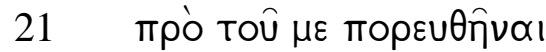

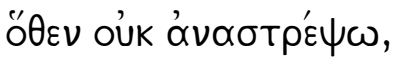

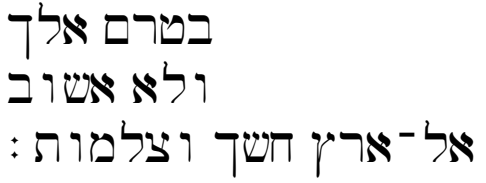

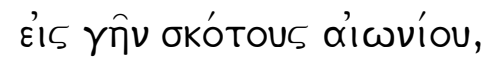

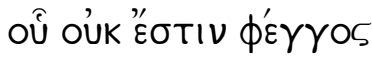

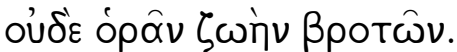

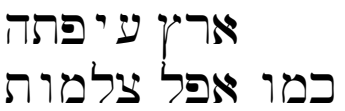

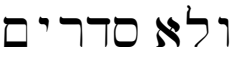

ותפע כמו -אפל : וארים

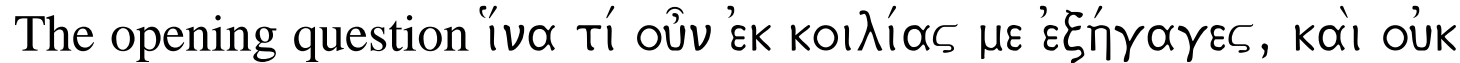

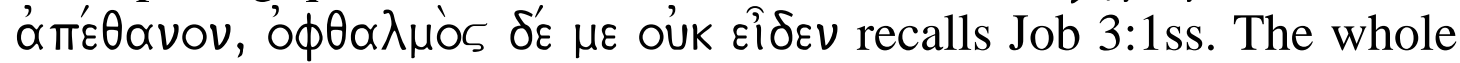
passage, however, gives an explicit listing of what does not mean

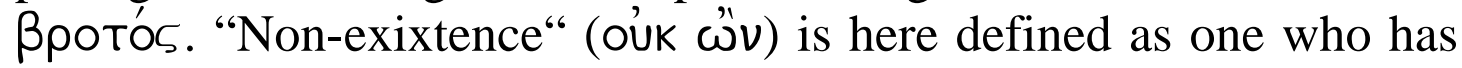
never been born from a woman and has come from the maternal womb directly into the grave, the matrix of the earth, the mother of all (10:19 cf. Sir 40:1). This first explanatio ex negatio of ßpotós as revuntós ruvasiós, reminds one of the philosophical term про́ßротоک by Diogenes Laertius (Vitae VIII 45.4). A witness of human existence is that human beings have been born and are able to perceive and be perceived by other human beings (10:18.22). Bpotós is ephemeral because he is shortlived (10:20). He exists as long as he has not yet gone the way from which there is no return; the way to the land of deep darkness, where there is no light and everything dies (10:22), human or plant.

4. On the basis of LXX-Job 14:1s we can first establish an explicit connection between $\beta$ potós and the plant kingdom, respectively the flowers as a symbol for the shortlived man.

1 Bpotós yòp yevvitós yuvaıikós

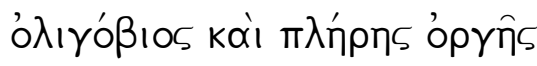

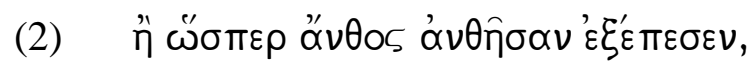

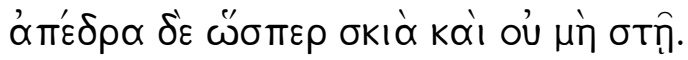

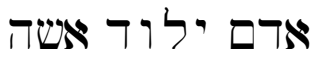
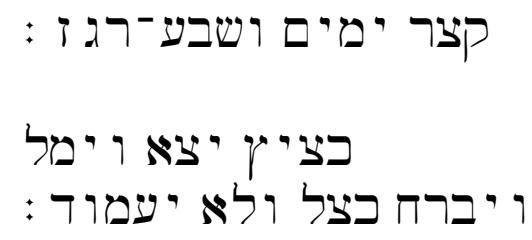
In LXX-Job 14:2, ßpotós is compared with a flower, which grows up and will wither away. But withering is not the end of a flower and death is not the end of Bpotós. This fact will be elucidated in LXXJob 14:10ss:

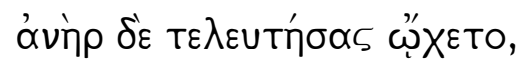

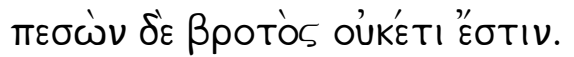

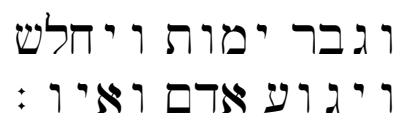

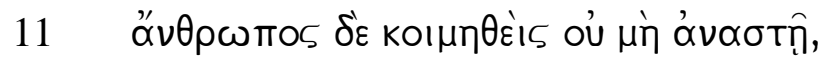

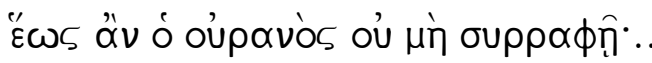

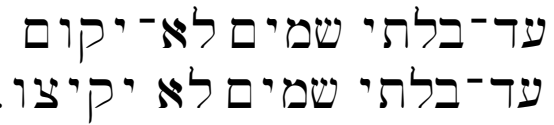

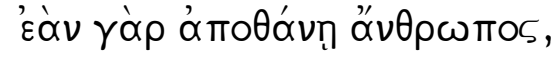

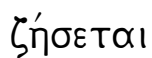

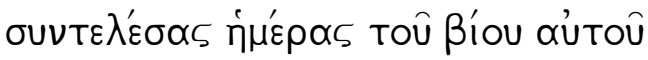

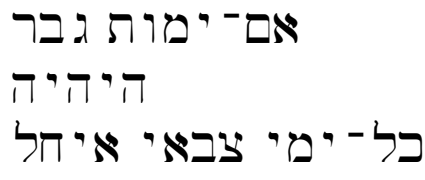

LXX-Job 14:10ss makes a clear difference between the life and earthly existence of ßpotós. According to LXX-Job 14:12 the end of the earthly existence is not identical with the end of life. In this way the belief in the resurrection and the eternal life with God, is indirectly expressed. In contrast to other Old Testament passages, which refer to the resurrection of a chosen individual person, here the focus is on a general resurrection that will take place at the end of earthly existence, when the heavens will be joined together (LXXJob 14:11).

\section{OUTLOOKS}

The Septuagint term ßpotós therefore does not refer to the man who is to die, the mortal one. It expresses and emphasizes the beauty of a complete human being, as an excellent creature of God, who is transient but strives to eternity, who is vulnerable but wants to reach perfection, who is mortal and longs for immortality ${ }^{79}$.

79 Cf. the speech of Eve to Adam according to Romanus Melodus, Cantica 11.3.4-4.6:

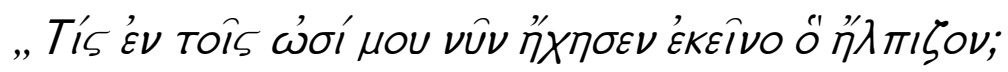

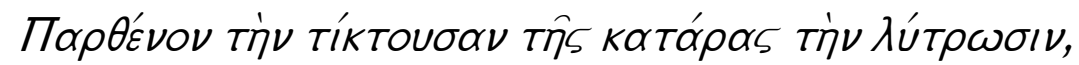

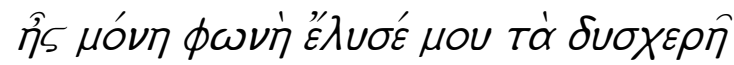

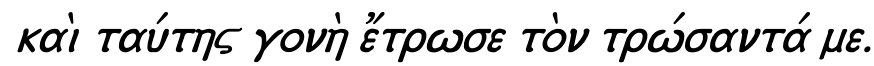

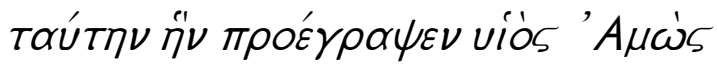

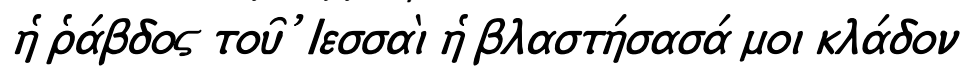

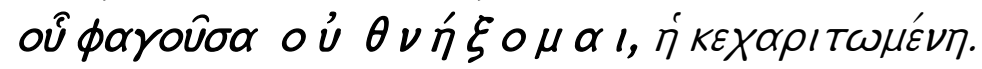


The ordering and the logic of the translation of the LXX-Job betrays the usage of extremely obstinate rules which seem mostly independent from the Hebrew source text (Vorlage).

The LXX translator offers his translation with a Genesis 2-3 and 6:3 motivation, as well as oriented interpretation of Bpotós. Special attention has been paid to Genesis 2:7 and 3:19, where two border situations of human existence are described: the beginning of his life and the end. Reflections have been presented on the cause or the origin of the limitedness of human life. Human beings are limited, because they are creatures and are not the Creator. Human beings are more limited, because they let themselves be tempted by evil and enticed to contravene God's rules.

The textual treatment indicates the abilities of its translator, simultaneously a poet, or at least a student of great Greek poets. The translator attempts to show, by means of exclusive vocabulary, the theological reason that no human being can be absolutely pure and righteous before God. He is not content with the populist view of the theodicy problem, but he tries to provide a theological explanation with the assistance of Homeric vocabulary, in this case ßporós. The parameters of this explanation are depicted in the various ßpotósoccurrences of LXX-Job.

If the final form of the Hebrew book of Job must be dated during the Hellenistic period ${ }^{80}$, then we can argue that the translator of Job must have had profound knowledge of the Homeric epics. Not only the translator of LXX-Job, but also the author/redactor/editor of the Hebrew text seems to share this knowledge, since the Hebrew text was shaped with in view of the course of events occurring in the Homeric Epics, especially in the Odyssey. The possibility should not be excluded that the Odyssey influenced the end-redaction of the

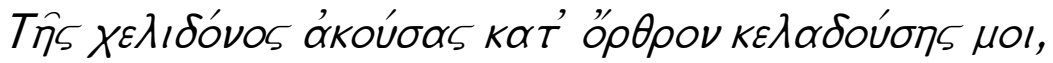

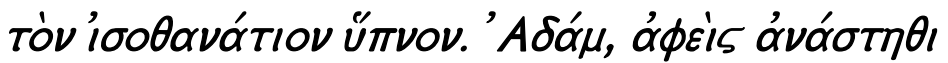

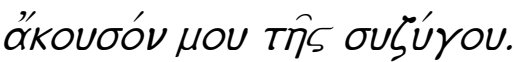

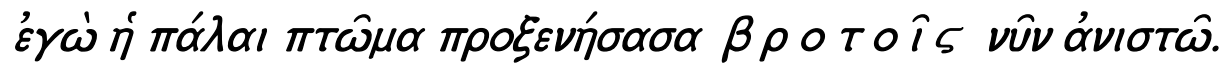

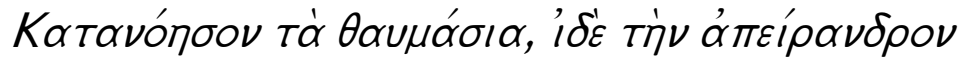

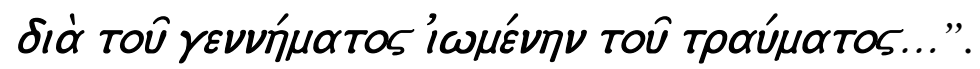

80 Of course with deviations and divergences from other Old Testament texts, which may be depend on the argument about Greek Polytheism and Hebrew Monotheism. 
prosaic parts of the Hebrew book of Job, ${ }^{81}$ because the time between the end-form of the Hebrew Vorlage of Job and its Greek translation could not have been so long. We can maintain that both authors/redactors/editors and the translator of the book of Job were hellenized and the book itself was a product of Hebrew religious belief in the soil of the Greek language and thought. Therefore, it is conceivable that the Job-translator consulted Homeric vocabulary to bring the content of the book of Job closer to the Greek reader.

\section{Consulted literature}

\section{a) Critical Editions}

Rahlfs, A (ed) (1935) 1979. Septuaginta: Id est Vetus Testamentum graece iuxta LXX interpretes, Duo volumina in uno, Stuttgart.

Ziegler, J (ed) 1982. Septuaginta: Vetus Testamentum Graecum, Auctoritate Academiae Scientiarrum Gottingensis editum, Bd. XI,4: Iob, Göttingen.

b) English re-translations of the $\mathrm{LXX}$

Brenton, L C L (1844) 1976. The Septuagint Version of the Old Testament and Apocrypha with an English Translation, London.

Cox, C E 2005. A New English Translation of the Septuagint and the other Greek translations traditionally included under that title. Iob. Provisional edition: http://ccat.sas.upenn.edu/nets/.

Thomson, C 1808. The Holy Bible containing the Old and the New Covenant, commonly called the Old and the New Testament, vols. 1-4, Philadelphia.

\section{c) Secondary Literature}

Barr, J 1961. The Semantics of Biblical Language, Oxford (=1965. Bibelexegese und Moderne Semantik. Theologische und linguistische Methode in der Bibelwissenschaft. Mit einem Geleitwort von H Conzelmann, transl. by E Gerstenberger, München).

Beer, G 1895/97. Der Text des Buches Hiob, Marburg.

-, 1896-98. Textkritische Studien zum Buche Job, ZAW 16, 297-314; ZAW 17, 97-122; ZAW 18, 257-286.

Bertram, G 1957.Preparatio Evangelica in der Septuaginta. VT VII, 225-249.

Bickel, G 1886. Der ursprüngliche Septuagintatext des Buches Job. ZKTh 10, 557-564.

81 It is remarkable that also the Pseudepigraphon TestJob 28:1, which explains exclusively the prosaic parts of Job (Rahmenerzählung) adopts from the Odyssey the scheme of twenty years wandering of Odysseus transforming it in twenty years suffering of Job. 


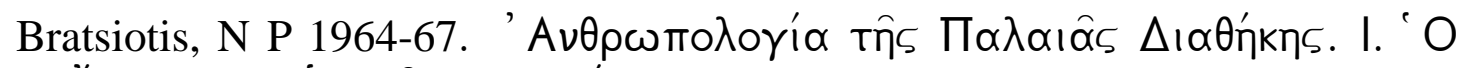

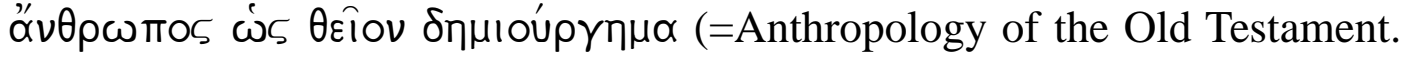
I. Man as God's creature). Athens.

-, 1973. Art. בשש, TWAT I, 850-867.

Caragounis, C C 2004. The Development of Greek and the New Testament. Morphology, Syntax, Phonology, and Textual Transmission. WUNT 167, Tübingen.

Cox, C E (ed) 1987. VI Congress of the International Organization for Septuagint and Cognate Studies, Jerusalem 1986. SBL.SCS 23. Atlanta GA: Scholars Press.

Cox, C E 1987. Methodological Issues in the Exegesis of LXX Job, in Cox, C E (ed), VI Congress, 79-89.

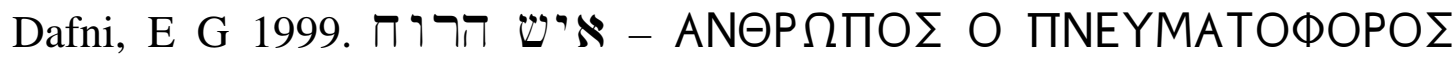
(Hosea 9,7). Zur Theologie der Sprache des Hoseabuches,' Emı

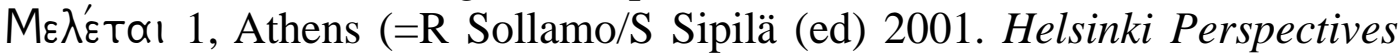
on the Translation Technique of the Septuagint, Publications of the Finnish Exegetical Society 82. Helsinki/Göttingen, 248-267.)

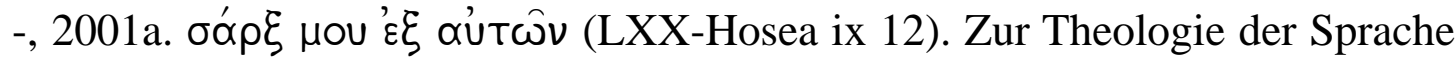
der Septuaginta, VT LI, 336-353.

-, 2001b. ßpotós. Von Homer zur Septuaginta, in Dafni, E 2001. Altestament-

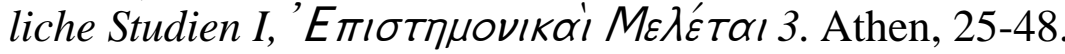

-, 2002. Theologie der Sprache der Septuaginta. ThZ 58, 315-328.

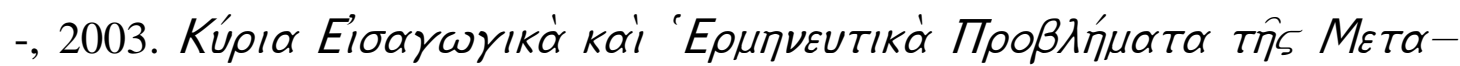

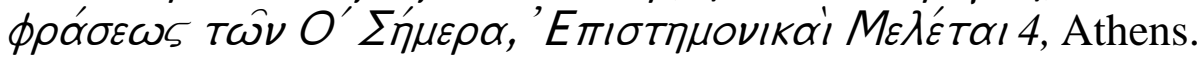

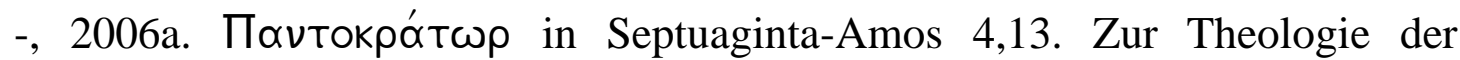
Sprache der Septuaginta, in M Knibb (ed), The Septuagint and Messianism. Colloquium Biblicum Lovaniense LIII, July 27-19, 2004, BETL 195, Leuven, 443-454.

-, 2006b. Noûs in der Septuaginta des Hiobbuches. Zur Frage nach der Rezeption der Homerepik im Hellenistischen Judentum. JSJ XXXVII, 3454.

Dhorme, E 1967. A Commentary on the Book of Job. Translated by H Knight with a prefatory note by H H Rowley, Leiden.

Fernández Marcos, N 1994. The Septuagint Reading of the Book of Job, in W A M Beuken (ed), The Book of Job. BETL 114, 251-266.

Gammie, J G 1985. The Angelology and Demonology in the Septuagint of the Book of Job. HUCA 56, 1-19.

-, 1987. The Septuagint of Job. Its poetic Style and relationship to the Septuagint of Proverbs. CBQ 49, 13-31.

Gard, D H 1953. The Concept of Job's Character according to the Greek translatos of the Hebrew text. JBL 72, 182-186. 
-, 1954. The Concept of the Future Life according to the Greek translator of the Book of Job. JBL 73, 137-143.

-, 1952. The exegetical method of the Greek transalator of the Book of Job. $J B L$, MS 8.

Gehman, H S 1949. The theological approach to the Greek translator of Job 115. JBL 68, 231-240.

Gerleman, G 1946. Studies in the Septuagint, I. Book of Job. Lunds Universitets Arsskrift, N.F. Avd. 1, Bd. 43/2, Lund.

-, 1971a. Art. בשש. THAT I, 376-379.

-, 1971b. Art. דם. THAT I, 448-451.

Gordon, C H 1955. Homer and Bible. The Origin and Character of East Mediterranean Literature, HUCA XXVI, 43-108.

Heater, H 1982. A Septuagint translation technique in the book of Job. CBQ.MS 11.

Hesychii Alexandrini MCMLIII, Lexicon, reccensuit et emendavit, K Latte (ed), Vol. I, Hauniae.

Kedar-Kopfstein, B 1977. Art. םד. TWAT II, 248-266.

Koch, K (ed.) 1972. Um das Prinzip der Vergeltung in Religion und Recht des Alten Testaments, WdF CXXV, Darmstadt.

Leibnitz, G W Freiherr von (1744) 1996. Theodicee. Das ist. Versuch von der Güte Gottes, Freiheit des Menschen, und vom Ursprunge des Bösen. Nach der 1744 erschienenen, mit Zusätzen und Anmerkungen von J.C. Gottschied ergänzten, 4. Aufl. herausgegeben, kommentiert und mit einem Anhang versehen von $\mathrm{H}$. Horstmann, Berlin.

Maass, F 1973a. Art.

-, 1973b. Art. אנ וש. TWAT I, 373-375

MacDonald, D R 2003. Does the New Testament Imitate Homer? Four Cases from the Acts of the Apostels. New Haven.

Matthäa Vock, M 1928. Bedeutung und Verwendung von ANHP und $A N \Theta P \Omega \Pi O \Sigma$. Diss-Freiburg, Schwitzerland.

Nagy, G 2004. Homer's Text and Language. Baltimore, Maryland.

Orlinsky, H M 1957.1958.1959.1961.1962.1964.1965. Studies in the Septuagint of the Book of Job, HUCA 28, 53-74. HUCA 29, 229-271. HUCA 30, 153-167. HUCA 32, 239-268. HUCA 33, 119-151. HUCA 35, 57-78. HUCA 36, 37-47.

Pietersma, A 1985. Review: Iob. Septuaginta: Vetus Testamentum Graecum 11,4 ed by J Ziegler. JBL 104, 305-311.

Snell, B 1979 \& 1991. Lexikon des Frühgriechischen Epos. Bd. 1: A, Bd. 2: BL, Göttingen.

Tebben, J R 1994-1998. Concordantia Homerica. Pars I-II. Hildesheim/Zürich/ New York. 
Thackeray, H St J 1915, The Septuagint. The International Standard Bible Encyclopedia. (http://www.bible.researcher.com/isbelxx).

Tov, E 1976. Three Dimensions of LXX Words. RB 83, 529-544 (= The Greek and Hebrew Bible, 85-94).

-, 1999. The Greek and Hebrew Bible. Collected Essays on the Septuagint. LXXII.

Westermann, C 1971. Art. אד. THAT I, 41-57. 